\title{
U-Pb ZIRCON CONSTRAINTS ON THE TECTONIC EVOLUTION OF SOUTHEASTERN TIBET, NAMCHE BARWA AREA
}

\author{
AMANDA L. BOOTH*, PETER K. ZEITLER**, WILLIAM S.F. KIDD***, \\ JOSEPH WOODEN****, YUPING LIU*****, BRUCE IDLEMAN**, \\ MICHAEL HREN*, and C. PAGE CHAMBERLAIN*
}

\begin{abstract}
The eastern syntaxis of the Himalayas is expressed in the crust as a pronounced southward bend in the orogen. The change in strike of geologic features coincides with the high topography of the Namche Barwa region, the exposure of granulite-grade metamorphic rocks, and a 180-degree bend in the Yalu Tsangpo. We have conducted a geochronologic and geochemical investigation of several suites of granitoids collected from the Namche Barwa massif and subjacent terranes of southeastern Tibet, ranging from $\mathrm{cm}$-scale dikes and sills to larger, outcrop-scale intrusions. U-Pb SHRIMP-RG zircon ages establish at least five magmatic episodes: $\sim 400$ to 500 $\mathrm{Ma}, \sim 120 \mathrm{Ma}, 40$ to $70 \mathrm{Ma}, 18$ to $25 \mathrm{Ma}$, and 3 to $10 \mathrm{Ma}$. These episodes broadly correlate to spatial patterns in sample localities, as follows: 400 to $500 \mathrm{Ma}$ ages occur in zircon cores collected from within the massif proper; $\sim 120$ Ma granites, related to early Gangdese arc plutonism, are primarily located northeast of Namche Barwa; later (40 - 70 Ma) Gangdese activity is expressed in granites west of Namche Barwa. 18 to 25 Ma granites occur both along the suture zone west of Gyala Peri, and directly north of Namche Barwa along the area of the Jiali fault zone, and are attributed both to shearing within the Jiali fault zone and to an early Miocene Gangdese Thrust event. Exceptionally young ( $<10 \mathrm{Ma}$ ) zircon ages are clustered near the core of the massif, along the Yalu Tsangpo gorge. Trace-element geochemical data indicates the presence of both fluid-present and fluid absent melts, with a fluid-absent (decompression) melting regime dominating near the core of Namche Barwa.
\end{abstract}

\section{INTRODUCTION}

Spatial and temporal patterns among Himalayan granites have been critical for reconstructing the tectonic framework of the India-Asia collision. Granite production and emplacement can be indicative of numerous different lithospheric melting regimes dominating within an area, such as decompression melting, shear heating, dehydration melting, et cetera (for example, Le Fort, 1975, 1981; Debon and others, 1985; Le Fort and others, 1987; Zeitler and Chamberlain, 1991; Harris and Massey, 1994; Scaillet and others, 1995; Harrison and others, 1998). Tectonic processes attributed with producing Himalayan crustal melts include syn-orogenic extension (Molnar and others, 1993; Fielding, 1996; Edwards and Harrison, 1997; Harrison and others, 1997a; Murphy and Harrison, 1999), fluxing by volatiles during thrusting along the Main Central Thrust (Le Fort, 1981; Le Fort and others, 1987), decompression melting during rapid denudation (Zeitler and others, 1993; Winslow and others, 1995; Whittington and Treloar, 2002), slab break-off (Miller and others, 1999; Chemenda and others, 2000; Yin and Harrison, 2000; Maheo and others, 2002; Kohn and Parkinson, 2002), continental subduction (Meyer and others, 1998; Wang and others, 2001), slab roll-back (Ding and others, 2003), slab detachment (Kosarev and others, 1999; Tilman and others, 2003), and subduction of remnant oceanic lithosphere (Murphy and Yin, 2003). Shear heating during strike-slip motion along the Red River

*Department of Geological and Environmental Sciences, Bldg. 320, Stanford University, Stanford, California, 94305; mbooth@pangea.stanford.edu 18015

**Department of Earth and Environmental Sciences, Lehigh University, Bethlehem, Pennsylvania,

***Department of Earth and Atmospheric Sciences, University at Albany, Albany, New York 12222

****U.S. Geological Survey, 345 Middlefield Road, Menlo Park, California 94025

*****Chengdu Institute of Geology and Mineral Sciences, Chengdu, China 
fault, southeast of Tibet, has also been ascribed with producing partial melts (Schärer and others, 1994; Leloup and others, 1995).

Southeastern Tibet is an area that remains sparsely studied with respect to its tectonic evolution, particularly its deeper structure and igneous history. Many features, however, can be readily observed that suggest a complex series of tectono-magmatic events has helped to shape this region, including: (1) The eastern syntaxis is expressed in the crust as a clear bend in the topographic, structural, and geological trends, particularly the Indus-Tsangpo Suture Zone (ITSZ) and the High Himalayan Crystalline belt; and (2) Embedded within the eastern syntaxis is an antiformal basement massif, Namche Barwa, where the deep gorge of the Yalu Tsangpo exposes $\sim 7000$ meters of actively deforming metamorphic rocks and granites as young as Pleistocene in age (Burg and others, 1997; Zeitler and others, 2001a).

This study deals with granitic melts present on a variety of scales in the eastern Himalayan syntaxis and southeastern Tibet. The results of our study suggest a complex tectonic history for southeastern Tibet, including at least five magmatic episodes and the production of both fluid-saturated and undersaturated melts.

GEOLOGIC AND TECTONIC OVERVIEW

An important element of understanding the tectonics of Southeast Asia is tracing the assembly of Tibet itself. Tibet proper consists of terranes accreted successively to the southern margin of Eurasia (Dewey and others, 1988; Murphy and others, 1997; Yin and Harrison, 2000; Kapp and others, 2003a, 2003b). The southernmost of these terranes is the Lhasa block, which originated by rifting from Gondwana in the late Paleozoic and was sutured to Asia by a late Jurassic-early Cretaceous collision $(\sim 140$ Ma). Subsequently, the southern Lhasa block was the site of an Andean-type magmatic arc until the India-Asia collision began in the Eocene. To the south, the Lhasa block is separated from rocks of Indian affinity in the Tethyan Himalaya by the ophiolitic ITSZ. The suture has been structurally modified, most likely by the south-directed Gangdese Thrust System (GTS; Yin and others, 1994; Harrison and others, 2000) and by back thrusts of the north directed Renbu Zedong Thrust System (RZTS; Yin and others, 1994, 1999; Ratschbacher and others, 1994; Quidelleur and others, 1997). Some workers, however, have interpreted the Gangdese thrust to be an unconformity, rather than an actual structure (that is, Aitchison and others, 2003).

The eastern Himalayan syntaxis represents a broad region over which structural trends in southeastern Tibet and the Himalayan orogen turn from E-W to N-S striking. This syntaxis is also evident in the trends of surface features such as major river valleys located along strike-slip faults (Hallet and Molnar, 2001), and overall the syntaxis likely reflects several generations of structural events along the eastern edge of the Indian plate, including Miocene extrusion tectonics (Wang and Burchfiel, 1997), and ongoing clockwise rotations (Burchfiel and others, 1998).

Near the peaks Namche Barwa and Gyala Peri, the eastern Himalayan syntaxis exposes both Indian and Asian continental components separated by a deformed ITSZ (fig. 1). The Gangdese or Transhimalayan Plutonic Belt (formerly part of the Asian plate margin) consists of Cretaceous and Paleogene calc-alkaline plutons intruded into Paleozoic and Mesozoic metasediments, and wraps around the antiformal Namche Barwa metamorphic massif (Zhang and others, 1992; Burg and others, 1997). Around much of the syntaxis, a mylonitic zone separates the Transhimalayan rocks from the core of Indian basement gneisses. Serpentine lenses and abundant amphibolites within this zone suggest that this boundary is the eastern continuation of the ITSZ, with remnants of meta-ophiolites separating Asian from Indian plate rocks (Zhang and others, 1992; Burg and others, 1997). A distinctive belt of metasedimentary rocks (dominantly quartzites and pelites, with some calc-silicates), thought to be a more deformed and metamorphosed equivalent of the Tethyan Himalaya, also form part of 


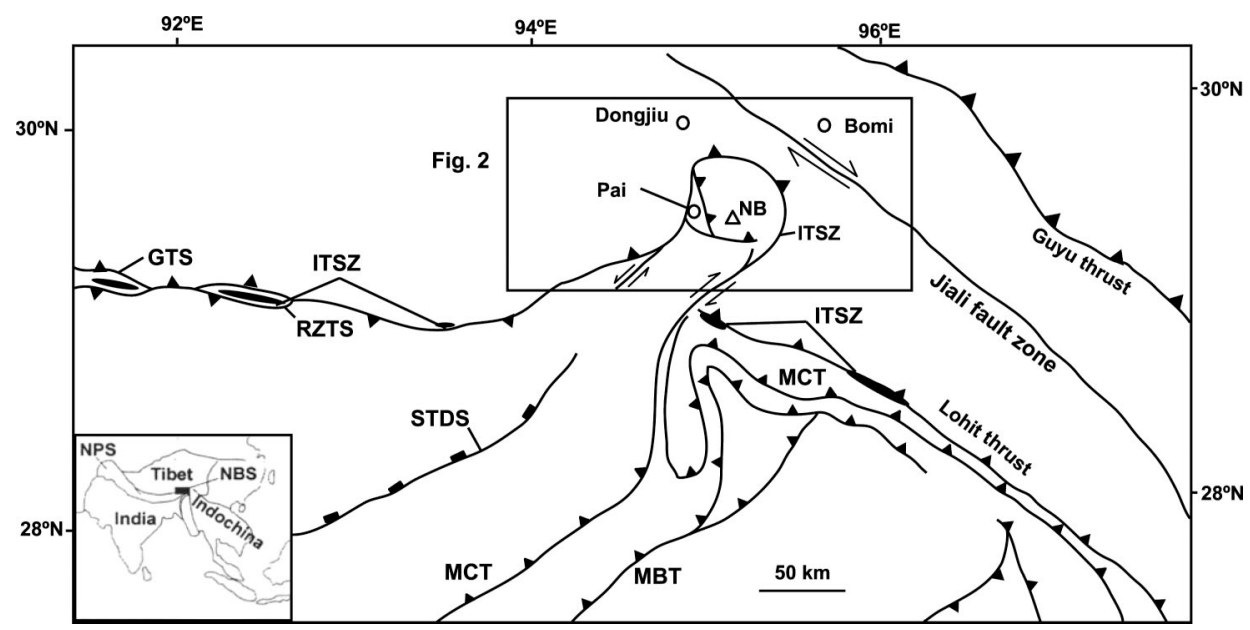

Fig. 1. Tectonic sketch map of southeastern Tibet, after Ding and others (2001). Location of fig. 2 shown in box. GTS = Gangdese Thrust System, RZTS = Renbu Zedong Thrust System, STDS = South Tibetan Detachment System, ITSZ = Indus Tsangpo Suture Zone, MCT = Main Central Thrust, MBT = Main Boundary Thrust, NB = Namche Barwa. Regional geographic location of Namche Barwa shown in inset. NBS = Namche Barwa Syntaxis, NPS = Nanga Parbat Syntaxis.

this zone of highly strained rocks. Medium to high-grade metamorphic rocks (presumably derived from Indian Basement rocks) make up the core of the syntaxis and were once structurally below the Transhimalayan Plutonic Belt. They are dominantly migmatitic gneisses of Proterozoic initial age (Zhang and others, 1992; Burg and others, 1997). According to Liu and Zhong (1997), they can be divided into a granulite group in the north and an amphibolite group in the south, with the former thrust over the latter by the Namula thrust system.

A number of granitoids with distinctly different means of formation occur within or near the eastern syntaxis. We briefly review the main types of granitoids that have been reported from the region to date.

Namche Barwa Massif. - In the core of this massif, granitic dikes and sills intrude Indian Basement gneisses on a range of scales. Burg and others (1998) reported leucogranite and pegmatite dikes in the Namche Barwa syntaxis, including leucosomes that crosscut metamorphic layering in the pelitic gneisses. This structural relationship indicates that anatexis has outlasted the main fabric development in the core of Namche Barwa. Single crystal U-Th-Pb analyses on zircon, xenotime and thorite by Burg and others (1997) provide leucosome crystallization ages ranging between 2.9 and 3.9 Ma, with a protolith age of $484 \pm 3 \mathrm{Ma}$. Ding and others (2001) reported U-Pb zircon ages as young as $\sim 11$ Ma from mafic granulites and two-mica-bearing leucosomes within the massif's core. A cluster of ages at $\sim 65$ Ma likely crystallized during Andean-type Gangdese magmatism, while a younger ( $\sim 40 \mathrm{Ma})$ cluster is interpreted to have crystallized during fluid-present, high-grade metamorphism during the early stages of India-Asia collision. The youngest, 11 to $25 \mathrm{Ma}$, zircon ages are attributed to a later high-grade metamorphic event, possibly related to decompression melting during rapid exhumation.

Nanga Parbat massif.- - In the western Himalayan syntaxis, decompression melting has been invoked for the formation of leucogranites that intrude the Nanga Parbat massif (Zeitler and Chamberlain, 1991), due to the temporal coincidence of exhumation and melting. In addition to fluid-absent (decompression) melting, fluid-present melts have been documented at Nanga Parbat. The concurrence of both types of melt 
reaction is attributed to a change from fluid-absent anatexis in the mid-crust $(\sim 20 \mathrm{~km}$ depth) to fluid infiltration in the upper crust $(\sim 10 \mathrm{~km}$ depth) (Whittington and others, 1999). These granites are among the youngest documented in the Himalayan system, at 1 to $3 \mathrm{Ma}$ (Zeitler and Chamberlain, 1991).

Himalayan leucogranites.-Tertiary magmatism within the Himalaya proper is largely confined to two parallel granite belts, the High Himalayan Leucogranites and the North Himalayan Granites (Harrison and others, 1997b). A commonly prescribed model for Himalayan leucogranite genesis involves fluid advection from the dehydrating footwall into the relatively hot hanging wall, along major fault systems such as the Main Central Thrust (Le Fort, 1981; Le Fort and others, 1987). Improved knowledge of granite crystallization ages (Edwards and Harrison, 1997; Harrison and others, 1997a) suggests a different model, relating the formation of Miocene leucogranites to syn-orogenic extension on the South Tibetan Detachment System (STDS) around 20 Ma. This model assumes that the primary cause of melting is decompression during exhumation south of the STDS (Hodges and others, 1992; Harris and Massey, 1994). In southeastern Tibet, Miocene partial melts and late Eocene K-rich magmas have been attributed to simultaneous shear heating and rapid erosion (for example, Harrison and others, 1998) during coeval slip along the MCT and STDS. An alternative slab break-off model (Chemenda and others, 2000; Yin and Harrison, 2000; Kohn and Parkinson, 2002) has been proposed to explain the Miocene leucogranites, based on the occurrence of rare Eocene eclogites in southeastern Tibet. This model assumes subduction of Greater Himalayan crustal rocks to $\sim 100 \mathrm{~km}$ depth in the Eocene followed by buoyant rise after decoupling from the mantle lithosphere.

Gangdese Arc.-Just to the north of the ITSZ is the Transhimalayan plutonic belt, a semi-continuous 2600-km-long batholith with rocks ranging in composition from gabbro to granite (Debon and others, 1986). In the proximity of the Namche Barwa syntaxis, this belt is represented by the Gangdese batholith, forming the root of the Gangdese magmatic arc that developed as a consequence of northward subduction of Neo-Tethys oceanic crust (Hodges, 2000, and references therein). Diorites and granodiorites from the eastern section of the Gangdese batholith yield geochronologic ages between $113 \pm 2 \mathrm{Ma}\left({ }^{40} \mathrm{Ar} /{ }^{39} \mathrm{Ar}\right.$ method on amphiboles; Maluski and others, 1988) and $41.1 \pm 0.4 \mathrm{Ma}(\mathrm{U} / \mathrm{Pb}$ method on zircons; Schärer and others, 1984). There is a wide variety in composition (that is, Debon and others, 1986), but no clear relationship between chemistry and age of plutonism (Schärer and others, 1984).

Red River shear zone. - East of the Namche Barwa syntaxis, documented magmatism is associated with ductile deformation and high-grade metamorphism along the Red River shear zone (Schärer and others, 1990, 1994; Harrison and others, 1992; Leloup and Kienast, 1993; Leloup and others, 1993, 1995; Chung and others, 1998; Wang and others, 2001). Partial melts in the Red River shear zone coeval with ductile deformation yield ages of 22 to $23 \mathrm{Ma}$ and geochemical data indicate anatexis at 20 to $15 \mathrm{~km}$ depth, with crustally derived mantle affinities (Zhang and Schärer, 1999).

Early Miocene melts, southern Tibet.-Two types of magmatism are documented in areas of southern Tibet from circa 25 to $10 \mathrm{Ma}$, those of ultrapotassic composition and of calc-alkaline composition (Coulon and others, 1986; Yin and others, 1994; Turner and others, 1996; Miller and others, 1999; Williams and others, 2001). These "postcollisional" magmas occur as small intrusive and extrusive bodies located west of Lhasa city. Recently, calc-alkaline magmas emplaced from circa 26 to 10 Ma have also been reported in the areas around Xigaze and east of Lhasa city (Chung and others, 2003), which exhibit geochemical signatures characteristic of adakites, lavas previously found only in subduction zones. Chung and others (2003) believe them to represent the first example of adakites produced in a modern continental collision setting, resulting from melting of thickened Tibetan lower crust, induced by removal of lithospheric 
mantle in late Oligocene time. Murphy and Yin (2003), however, suggest that postcollision (Oligocene/Miocene) high-K, calc-alkaline magmatism along the southern margin of the Lhasa block may be attributed to late subduction of remnant Neo-Tethyan oceanic crust, producing magmatism.

Himalayan Paleozoic ages. - Le Fort and others (1980) first reported Paleozoic ages (516 $\pm 6 \mathrm{Ma}$; whole rock $\mathrm{Rb} / \mathrm{Sr}$ method) on the Manshera granite in Pakistan. Recent work in the central Himalayas (Gehrels and others, 2003) also documents the existence of $\sim 470$ to $485 \mathrm{Ma}$ granitic intrusions (U-Pb method on zircons) within Greater Himalayan metasediments, reflecting initiation of the Himalayan orogen along an early Paleozoic thrust belt. This age range is also supported by numerous $\sim 480$ to $500 \mathrm{Ma}$ U-Pb zircon ages (Ferrara and others, 1983; Trivedi and others, 1984; Le Fort and others, 1986; Hodges and others, 1996; DeCelles and others, 1998, 2000; Miller and others, 2001) from cross-cutting granitic plutons and orthogneisses within Greater Himalayan rocks.

\section{METHODS}

Samples.-During September-October 2001 and May-June 2002 field seasons, our samples were gathered from five principal areas, and can be grouped as follows: [A] within the Namche Barwa massif (fig. 2) - from granitic dikes and migmatites intruding Indian plate gneisses and metasediments; [B] along the northwest margin of the Namche Barwa-Gyala Peri (NB-GP) massif - from granitic intrusions into both Lhasa block and Indian plate gneisses and metasediments; [C] substantially west of the NB-GP massif, spread out from Loulan toward Bayi, and along the Nyang River intruding Lhasa block gneisses and metasediments; [D] north of Namche Barwa, along the inferred location of the Jiali Fault zone - from intrusions into Lhasa block gneisses and metasediments; and [E] northeast of Namche Barwa near the Jiali Fault zone from presumed Gangdese plutonic rock of granodioritic compositions.

Group A samples, collected from within the Namche Barwa massif proper, are 20 to $300 \mathrm{~cm}$-thick dikes and sills that intrude amphibolite to granulite grade Precambrian gneisses. Samples IG-2d, IG-4, and IG-6b were collected along the upper inner gorge of the Yalu Tsangpo (fig. 2), along a traverse from Jiala to Zhibei. Sample IG-2d (fig. 3) represents a deformed felsic melt pod within a 100-meter amphibolite section near Jiala. Sample IG-4 was collected from an $\sim 3$-meter leucocratic pegmatite dike that locally crosscuts and elsewhere is sheared concordantly into the foliation. Sample IG-6b was collected from a felsic crosscutting dikelet $(\sim 20 \mathrm{~cm})$ within a small biotite gneiss outcrop exposed along the trail from Zhibei to Jiala, just northeast of Zhibei. Sample IG-15a was collected from a granitic sweat within the gneisses, along a road cut just to the east-northeast of Pai. Sample IG-16 was collected from a K-feldspar-bearing banded migmatite exposed along a jeep road from Pai to Duoxiong La, on the northwest side of Duoxiong La pass. Sample IG-18 was collected as float from an $\sim 4 \mathrm{~m}$, coarse-grained granitic boulder halfway to the top of Duoxiong La pass. The source of this boulder, however, was clearly from a large granite sill visible in the headwall above. We therefore justify the sampling of float in the case of IG-18, by asserting that the source rock is very well constrained.

Group B samples were collected along the northwestern margin of the NB-GP massif, and represent granite and pegmatite dikes intruding basement gneisses of both Lhasa block and Indian Plate origin. Samples BT-14, BT-15, BT-17 (fig. 4), BT-19, and BT-20 were collected from a section within the De'u Gungbu Valley (fig. 5), along an E-W traverse across the brittle-faulted western margin of the NB-GP massif (including the modified and very narrow Indus-Tsangpo suture zone). Within this group, BT-14 is a granitic gneiss, BT-15 represents a leucocratic pegmatite dike cross-cutting the Lhasa Block basement gneisses, BT-17 is a medium-grained granite dike from the westernmost edge of the Gyala Peri massif, cross-cutting the amphibolites near a brittle fault 


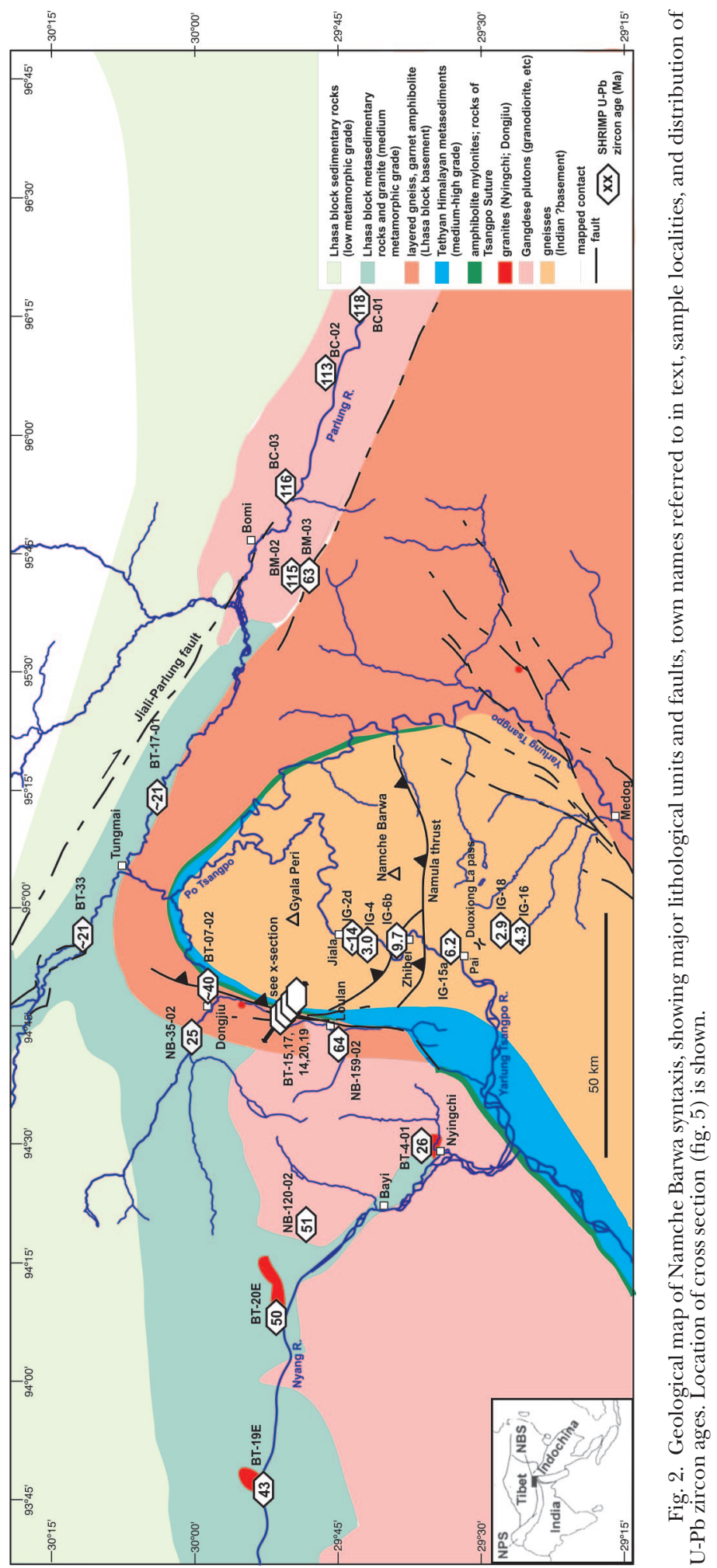




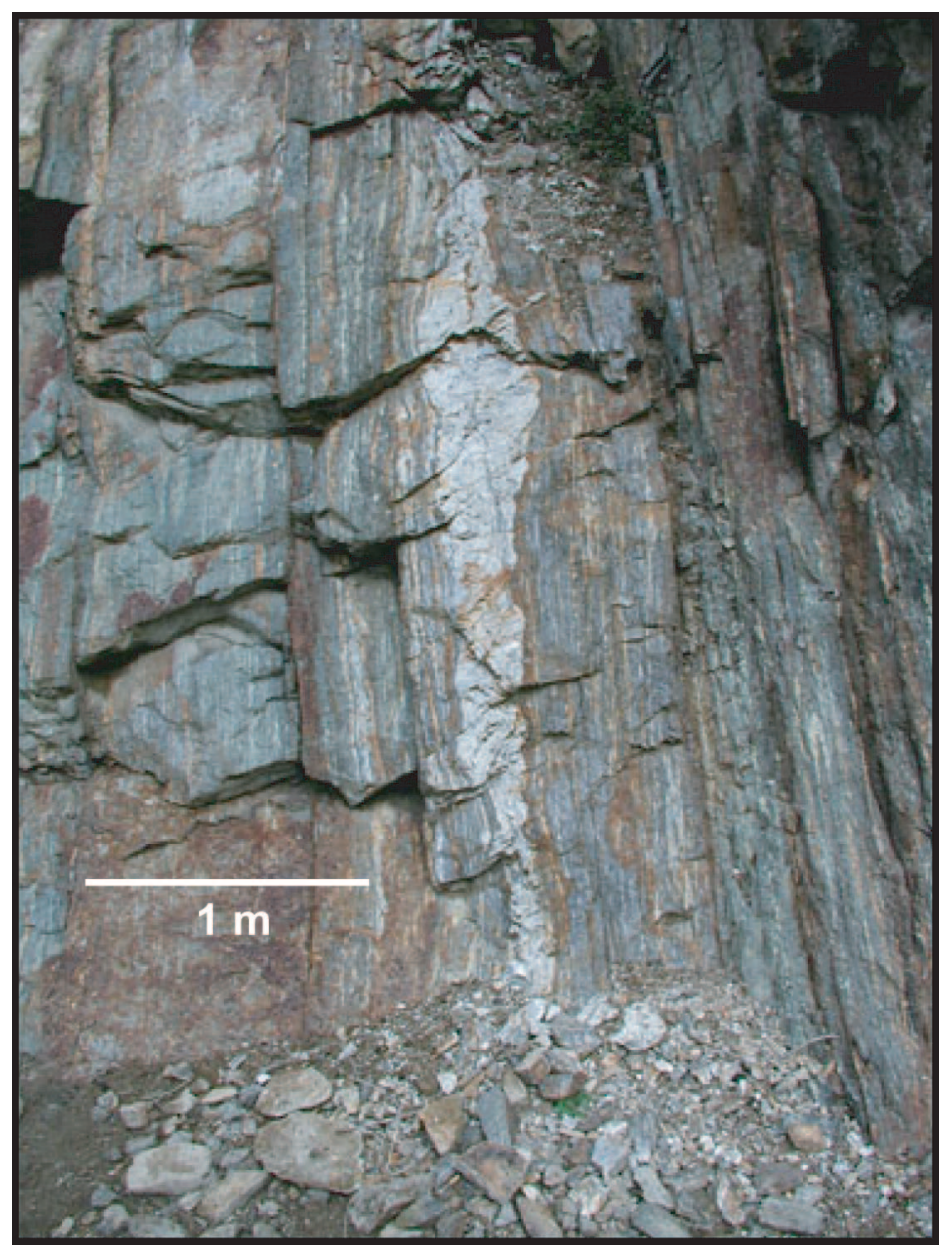

Fig. 3. Sample IG-2d - Deformed felsic melt pod ( $~ 50 \mathrm{~cm}$ across $)$ within amphibolite section near Jiala.

zone, BT-19 is a syntectonic foliated muscovite-bearing granite east of the S/C mylonite zone, and BT-20 is a S/C mylonite with coarse augen. North of this traverse, BT-07 and NB-35-02 were collected near Dongjiu, from a garnet granite cutting Lhasa block gneisses and a granite cutting Lhasa metasediments, respectively.

Group C samples were collected from a large area west of the NB-GP massif. Sample NB-159-02 was collected from Lhasa block basement granitic gneiss near Loulan. Samples NB-120-02, BT19E, BT20E, BT-4-01 are spread out to the west of the NB-GP massif, in the general vicinity of Bayi and along the Nyang River. These, along with samples BT-36 and BT-37 (located considerably west, off the map, along the road to Lhasa from Bayi) most likely represent outcrops of Gangdese Arc granitoids.

Group D consists of two samples, BT-33 and BT-17-01 (2001 field season), collected from roughly north of the Namche Barwa massif, near Tungmai, in the area of the Jiali fault zone. Both represent granitic dikes intruding Lhasa Block metasediments of medium grade.

Group E samples were collected from northeast of Namche Barwa, in the vicinity of Bomi. Samples BM-02 and BM-03 represent Gangdese plutonic rock and were 


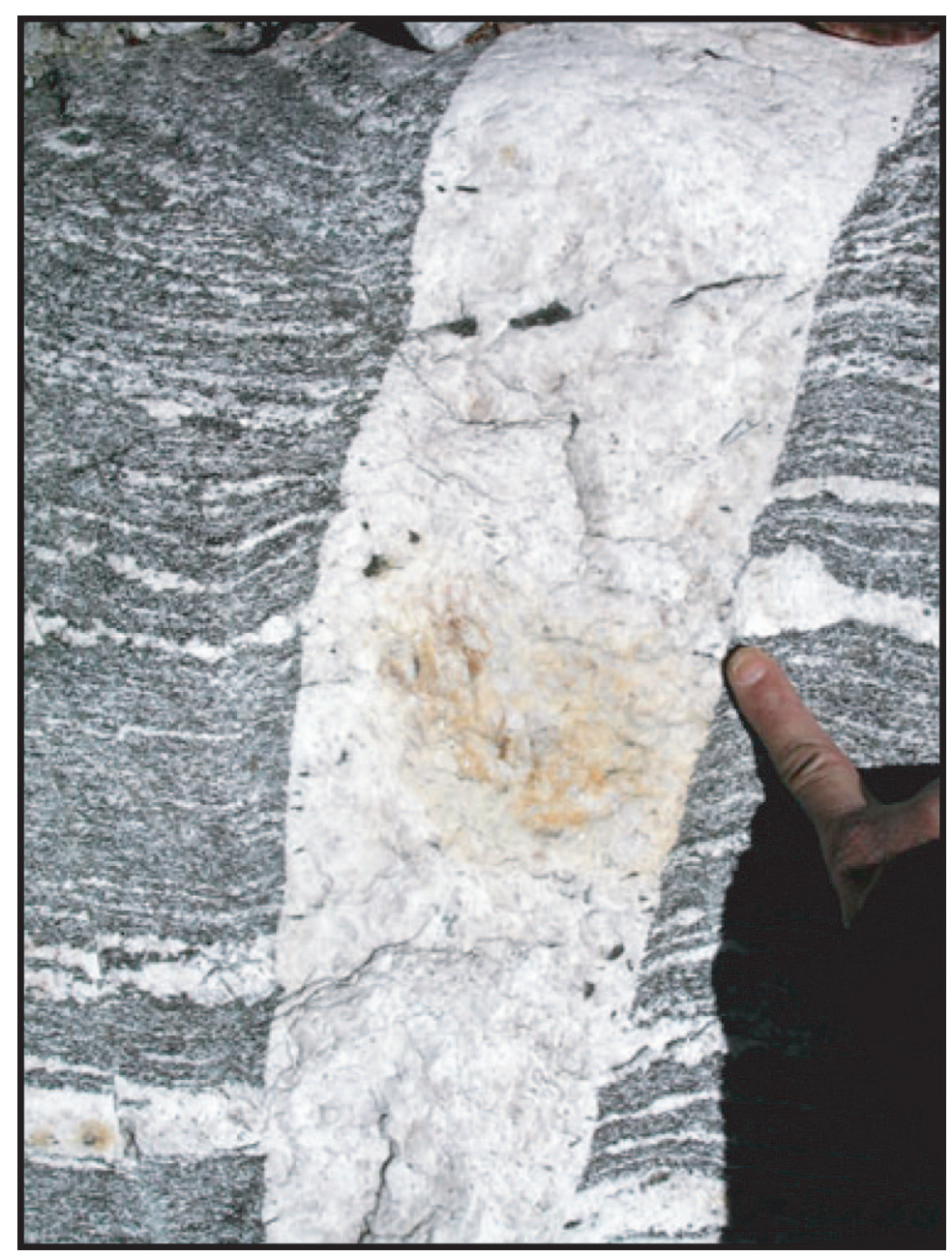

Fig. 4. Sample BT-17-02 - Pegmatite dike cross-cutting basement gneisses, De'u Gungbu section, western margin of Gyala Peri massif.

collected from a granodiorite and a granite pegmatite dike, respectively, between Medog and Bomi. Samples BC-01, BC-02, and BC-03 are also Gangdese granitoids, collected along the main road to Qamdo and Chengdu, east of Bomi.

Mapping procedures. - The map (fig. 2) is based on the work of our Chengdu colleagues (Geng and others, 2002), modified and extended using observations made during our field work. Portions of original maps by Zhang and others (1992) and Burg and others $(1997,1998)$ for the eastern part of the syntaxis are also incorporated into figure 2.

Analytical techniques and considerations.-At the Stanford - U.S. Geological Survey Mass Analysis Center, we determined SHRIMP-RG (Sensitive High-Resolution Ion Microprobe - Reverse Geometry), U-Pb ages for all of the samples in this study. Zircons were separated using standard techniques of crushing, grinding, and heavy liquid and magnetic separation. Analyzed zircon fractions were primarily composed of clear, euhedral grains, and consistently exhibited one of two morphologies: elongate prisms 


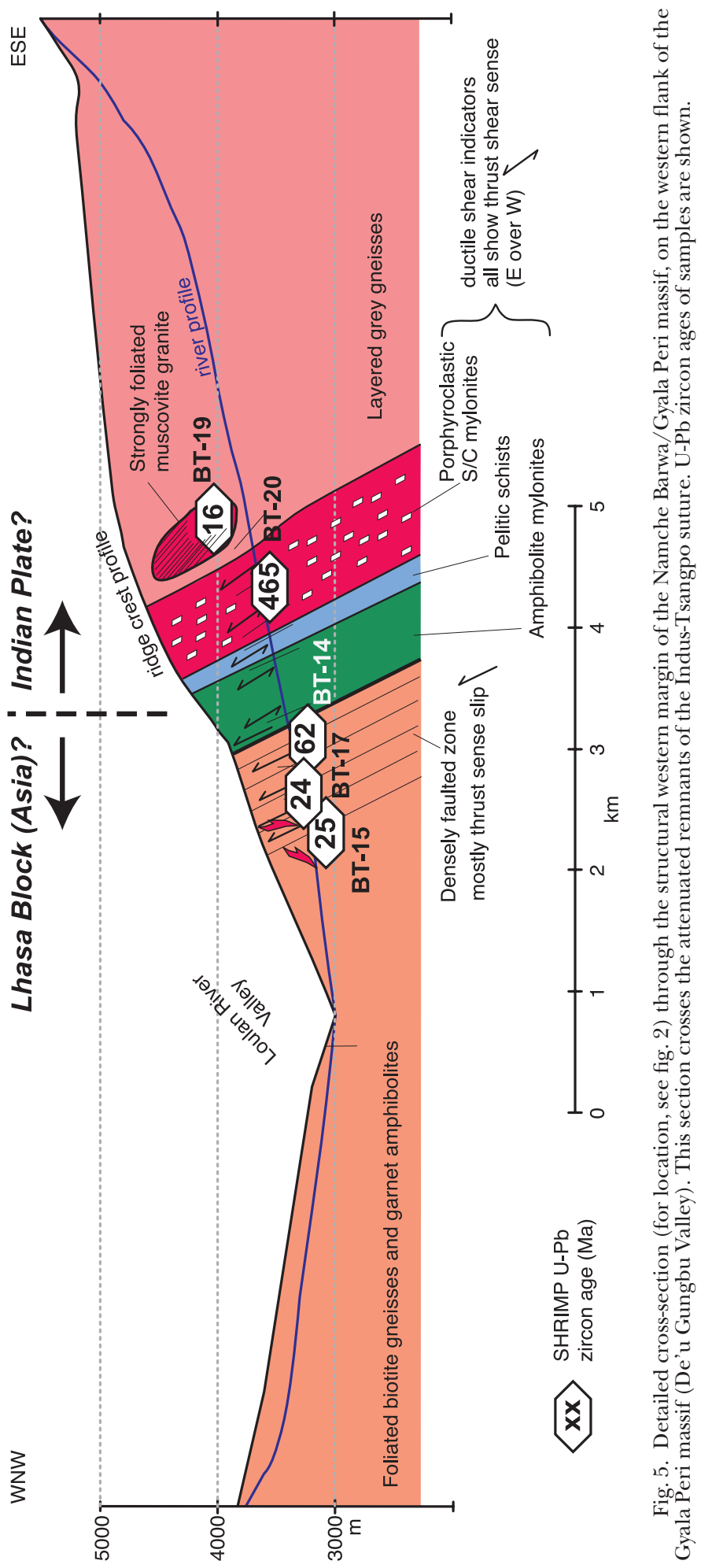



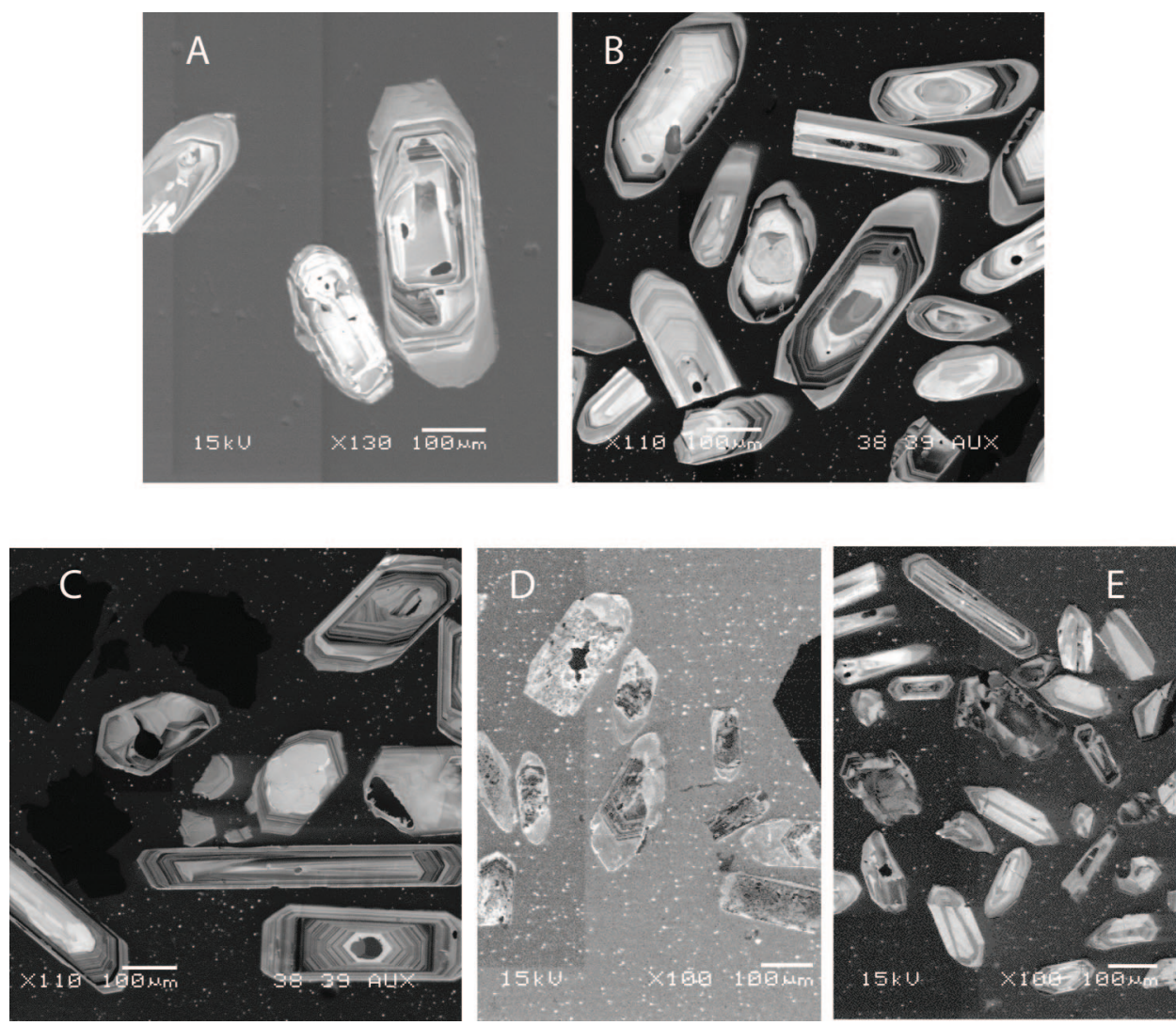

Fig. 6. Cathodoluminescence (CL) images of representative zircons from each sample group: (A) Namche Barwa (IG-16), (B) Northwest margin of NB-GP massif (BT-20), (C) Western Gangdese and related granitoids (NB-120), (D) North of Namche Barwa group (BT-33), and (E) Northeastern granites (BM-03), all showing strong zoning patterns.

or stubby prisms. Mineral coloring was honey yellow to light pink, with occasional inclusions of quartz, feldspar and biotite. Zircons from all sample groups were strongly zoned, and exhibited distinct cores with complicated overgrowths (fig. 6).

For each sample, separates were mounted in epoxy and polished to approximately half the mean grain thickness, then imaged with reflected light and cathodoluminescence to illuminate internal zoning. The mounts were coated with gold for analysis and each sample was sputtered by using a primary beam of $\mathrm{O}^{-}$ions with a spot size of $\sim 25$ $\mu \mathrm{m}$. Counts of $\mathrm{Zr}_{2} \mathrm{O},{ }^{204} \mathrm{~Pb}$, background, ${ }^{206} \mathrm{~Pb},{ }^{207} \mathrm{~Pb},{ }^{208} \mathrm{~Pb},{ }^{238} \mathrm{U},{ }^{248} \mathrm{ThO}$, and ${ }^{254} \mathrm{UO}$ were measured from the secondary beam. Analytical and data reduction procedures followed those given in Williams (1998). For age standardization, concentrations of uranium and thorium from standard zircons SL13 and CZ3 were used. U/Pb ratios were determined through replicate analyses of standard zircons R33 (418 Ma) and AS57 (1099 Ma), and ages were based on the measured ${ }^{206} \mathrm{~Pb} /{ }^{238} \mathrm{U}$ ratio calibrated to the ${ }^{206} \mathrm{~Pb} /{ }^{238} \mathrm{U}$ ratio in the AS57 standard. The $\mathrm{Pb} / \mathrm{U}$ ratio in the standard typically exhibited a calculated external spot-to-spot error of $\sim 2.0 \%(2 \sigma)$. All reported ages were determined using the data-reduction program Squid (Ludwig, 2001). Common $\mathrm{Pb}$ corrections were made using the two-stage average crustal $\mathrm{Pb}$ model of Stacey and Kramers (1975). Analyses yielding ages greater than 1000 Ma we corrected by using 
measured ${ }^{204} \mathrm{~Pb}$, while younger ages were corrected using measured ${ }^{207} \mathrm{~Pb}$. Because our samples are primarily young (Mesozoic and younger), Tera-Wasserburg concordia plots are chosen as the most appropriate to display the analytical data (figs. 6-10).

Major and trace element analyses for 37 Namche Barwa area granites were obtained by employing conventional XRF (X-ray fluorescence) spectrometry at the Washington State University GeoAnalytical Laboratory. Of these, three samples (BT1402, BT19E-02, NB02-159) included weathered pieces in those that were ground for analysis. All had good XRF totals, however, indicating that the amount of latealteration hydrous material was not significant.

RESULTS

Geochronology.-Our new U-Pb zircon ages place significant constraints on the timing of granitic melt generation in the Namche Barwa and adjacent regions. Analytical results (table 1) are shown on Tera-Wasserburg concordia plots in figures 7 , $8,9,10$ and 11 . The majority of the ages are concordant, with some older, slightly discordant ages resulting from inheritance, as would be expected from crustallyderived partial melts.

As the scope of our study is focused primarily on correlations between age and location, we emphasize that the procedures used for age assignments are not statistically rigorous, such as a more precise age-focused study would be. The wide range of the determined ages allows us to make groupings based on spatial trends; these groups are distinct from each other, and do not overlap within a 95 percent confidence interval.

Final ages were assigned using the weighted mean 207 -corrected ${ }^{206} \mathrm{~Pb} /{ }^{238} \mathrm{U}$ age of a coherent group, discounting points that showed abnormally high $\mathrm{U}$, high ${ }^{204} \mathrm{~Pb}$, or discordance. The assigned age for each sample is presented with its concordia diagram, along with the age error $(2 \sigma)$, number of analyses, and mean square of weighted deviates (MSWD) for the coherent group. Values of MSWD greater than one are indicative of errors beyond those strictly associated with analytical errors, and suggest geologic errors such as outliers or samples from more than one population are contributing to the overall age range. In samples where distinct core and rim populations were present, the final age always represents the rim age; core ages are plotted separately on a collective diagram, one per sampling group. Coherent age groups were extracted using a minimum 5 percent probability-of-fit, and a minimum 30 percent fraction of the total analyses to constitute a valid age group. In cases where no coherent age group was apparent, the age we present is an inferred age, chosen to be the most likely crystallization age for that sample based on the available data points. Because we are focusing primarily on the broad tectonic implications of these zircon ages, inferred ages are treated with equal consideration in our conclusions. The ages exhibit ranges that are geographically distinct, as can be seen in figure 2, and correspond to the five principle sampling groups previously outlined:

[A] For samples from within the Namche Barwa massif, five U-Pb SHRIMP ages fell between 2.9 and $9.7 \mathrm{Ma}$ (fig. 7). Concordant core ages cluster around 400 to 500 Ma and 800 to $900 \mathrm{Ma}$. Details of each sample are as follows:

For sample IG-2d, 11 rim spots and 11 core spots were analyzed. Of the $11 \mathrm{rim}$ ages, no coherent age group was apparent; several of these ages are a likely reflection of mixing between rim and core compositions; however, six ages fall between 13 and 15 Ma. The age presented $(\sim 14 \mathrm{Ma})$ is an average of these six ages, and is therefore approximate. In sample IG-4, 9 spots were analyzed; all were rim ages. The coherent age group was comprised of 4 spots, yielding a final (weighted mean) age of 3.0 Ma. In sample IG-6b, 10 rim spots and 7 core spots were analyzed. 9 rim ages comprised a coherent group, with a weighted mean of 9.7 Ma. In sample IG-15a, 10 rim spots and 4 core spots were analyzed. Both core and rim spots, however, yielded the same age 


\begin{tabular}{|c|c|c|c|}
\hline $\mathbb{Z}$ & 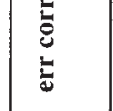 & 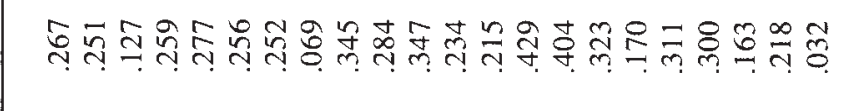 & 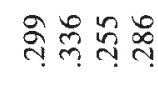 \\
\hline 恣 & 8 & 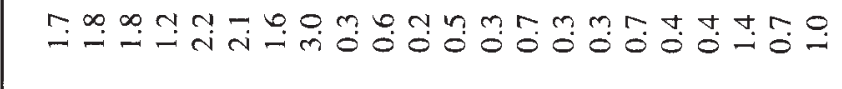 & $\stackrel{0}{\dot{m}} \underset{\dot{r}}{\rightarrow} \stackrel{\infty}{\rightarrow} 9$ \\
\hline ఫ্ & 商望 & 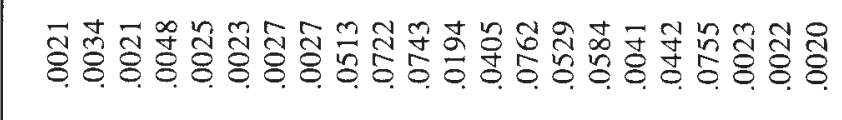 & 告苍号 \\
\hline sing & 5 & 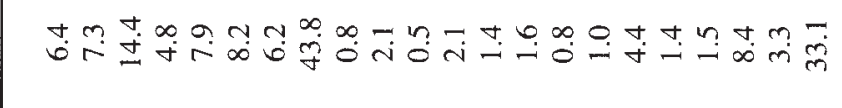 & 공ำ \\
\hline है & 点乎 & 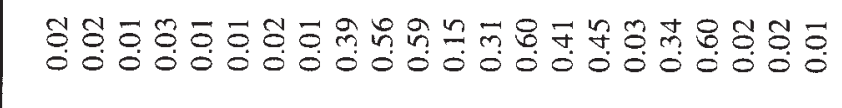 & 8888 \\
\hline$\approx$ & 48 & 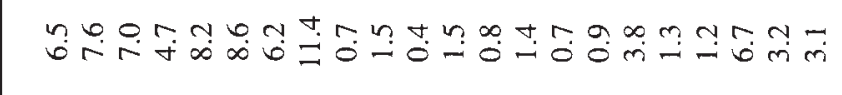 & $\stackrel{m}{\dot{ \pm}} \ddot{m}$ \\
\hline$\approx$ & 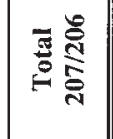 & 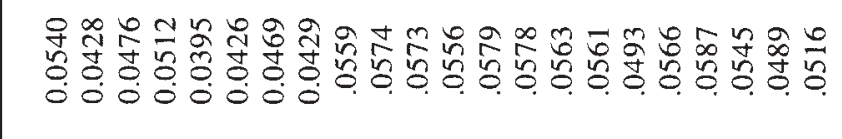 & 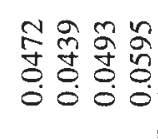 \\
\hline$\approx$ & 58 & 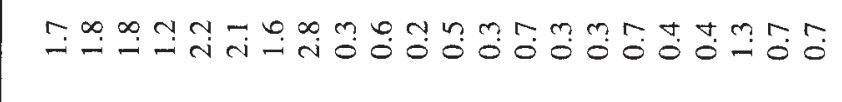 & $\stackrel{0}{m} \stackrel{0}{\dot{*}}$ \\
\hline & 焉旁 & 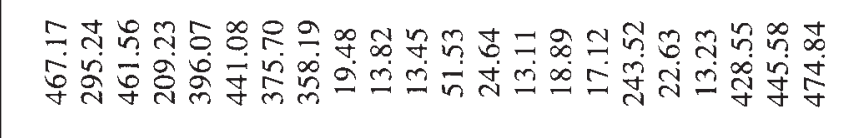 & 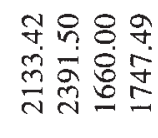 \\
\hline है & $\because 5 \frac{\pi}{3}$ & 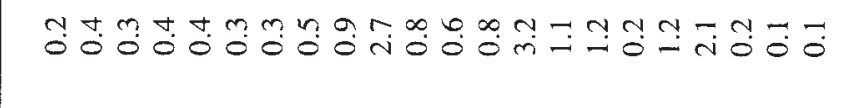 & $\overrightarrow{0} \overline{0} \overline{0} \overrightarrow{0}$ \\
\hline हूँ & 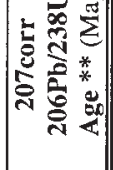 & 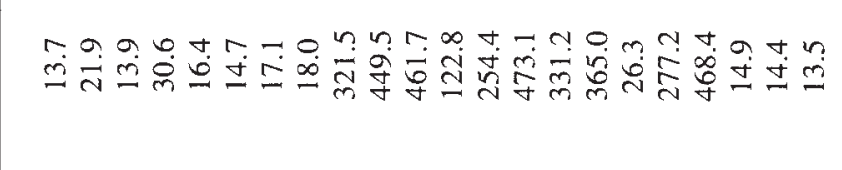 & लें்̃ \\
\hline .3 & 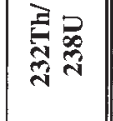 & 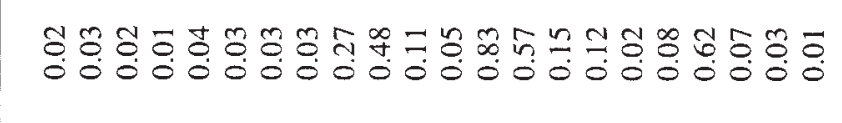 & $\begin{array}{ll}50 \\
0 & 0\end{array}$ \\
\hline 0 पे & 至言 & 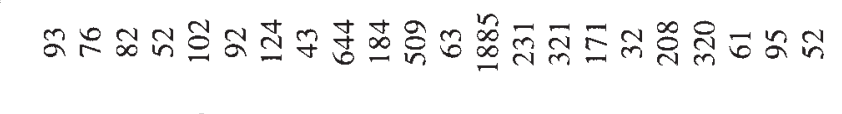 & जis \\
\hline हें & $\supset \widehat{\bar{g}}$ & 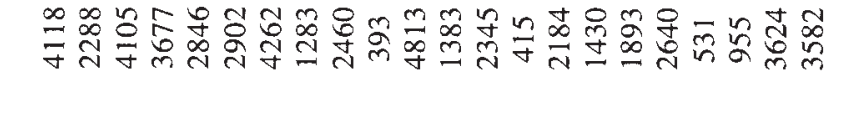 & 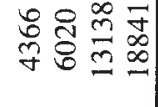 \\
\hline 2. & 焉 & 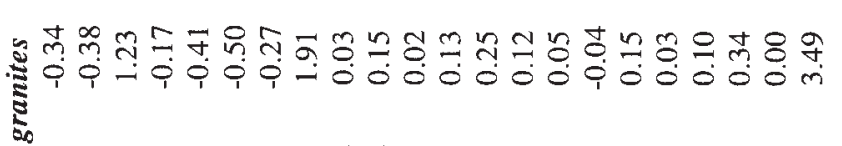 & 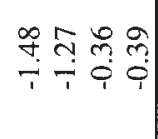 \\
\hline 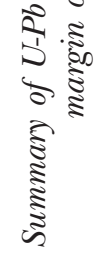 & 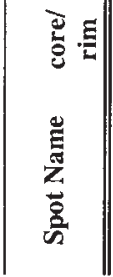 & 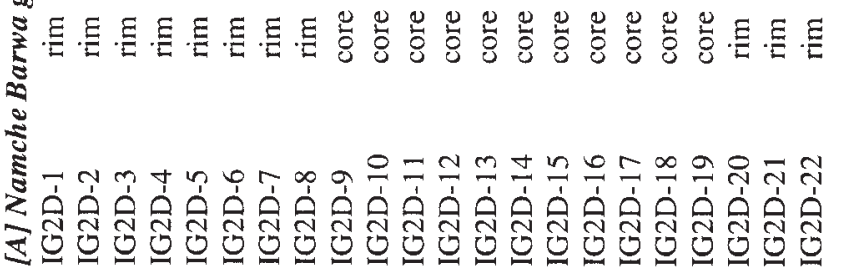 & $\Xi\{$ \\
\hline
\end{tabular}




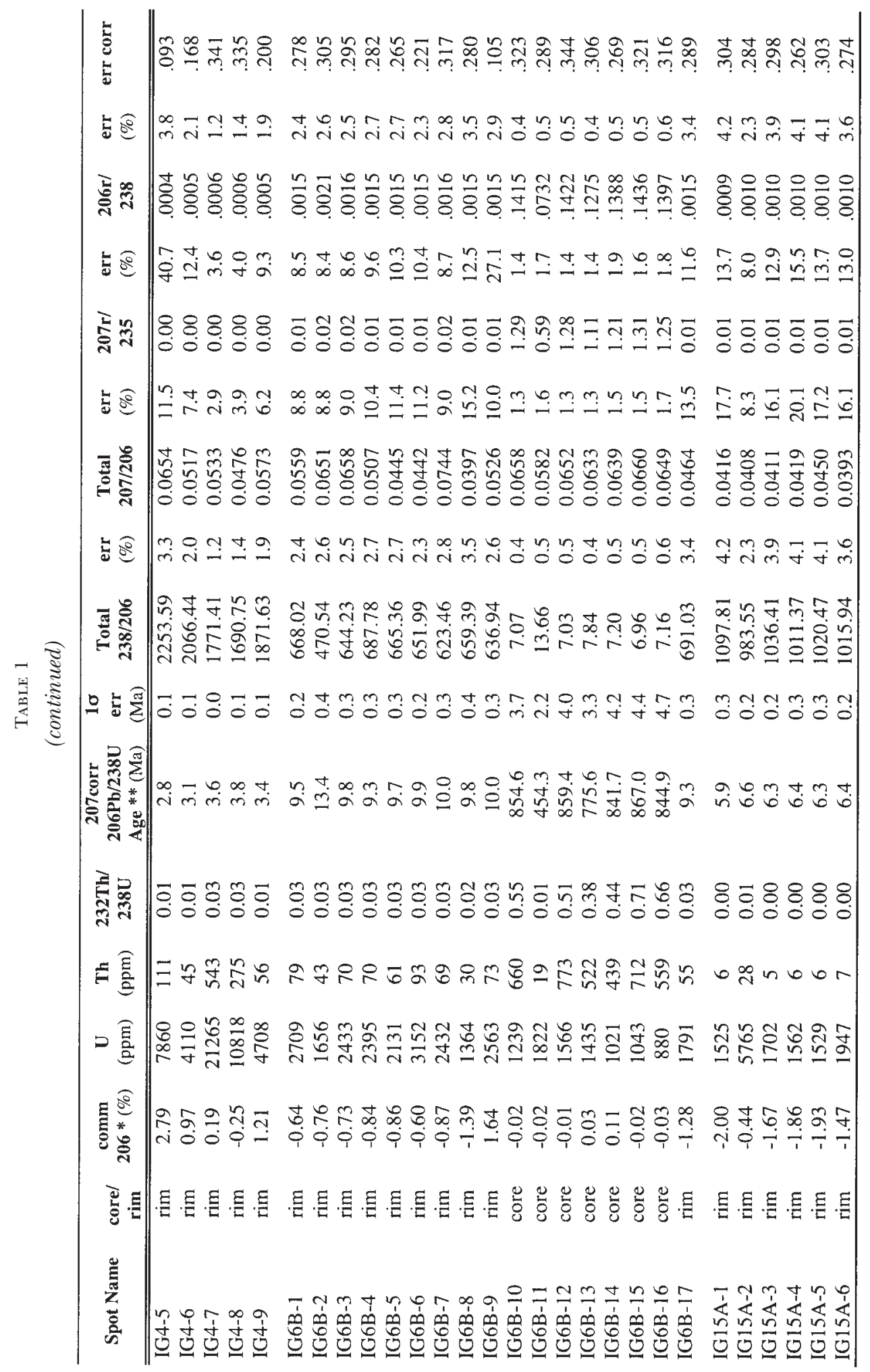




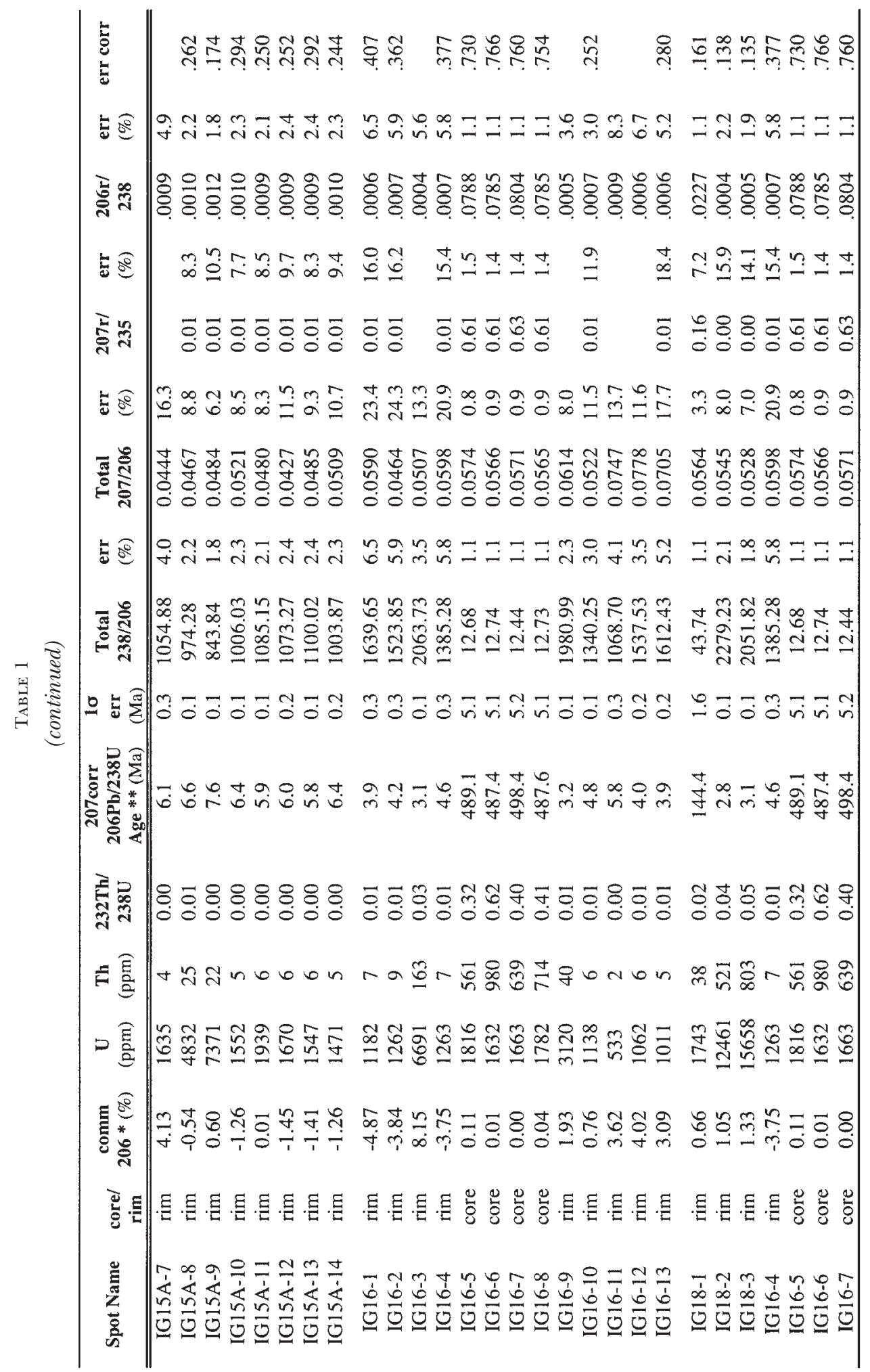




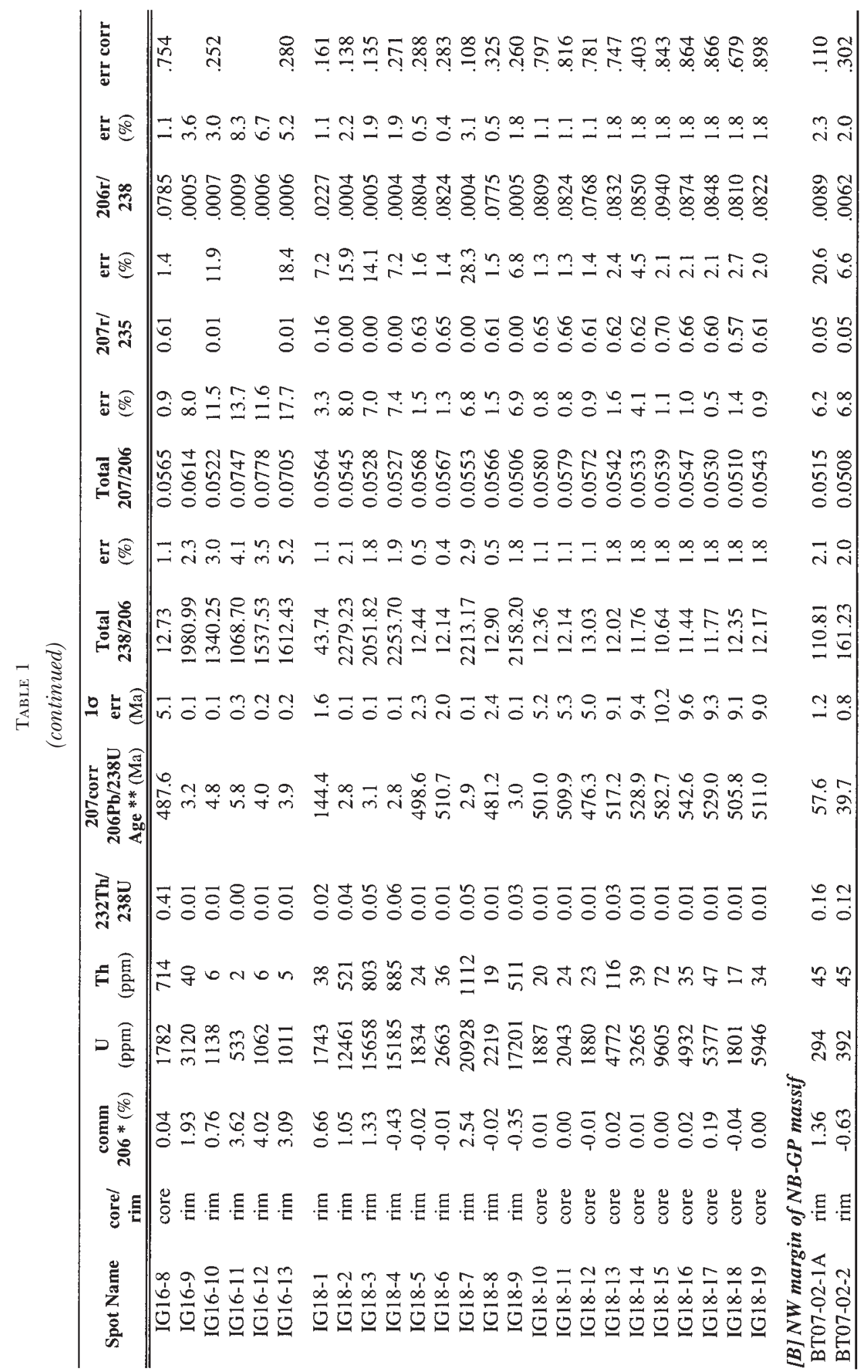




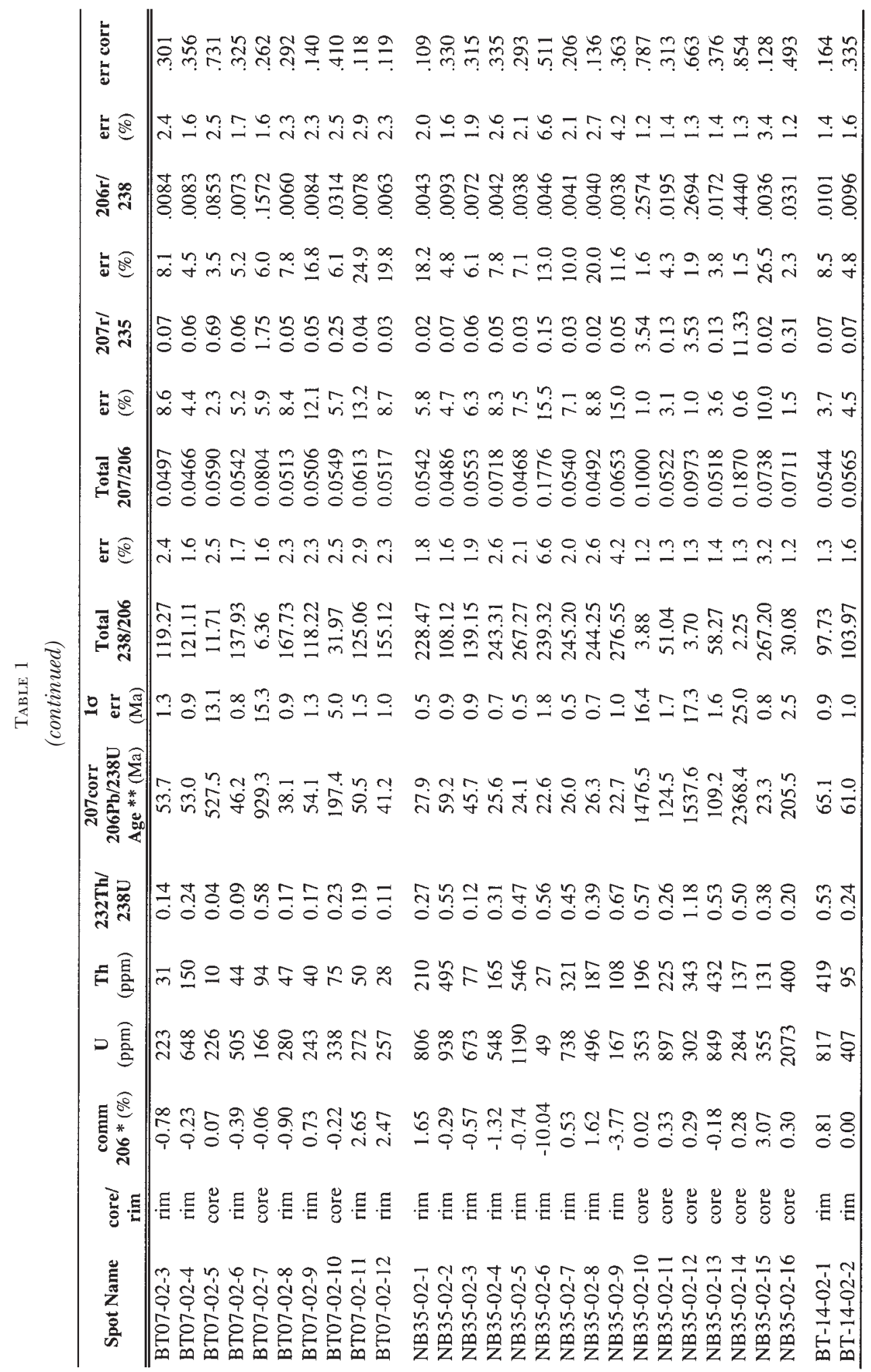




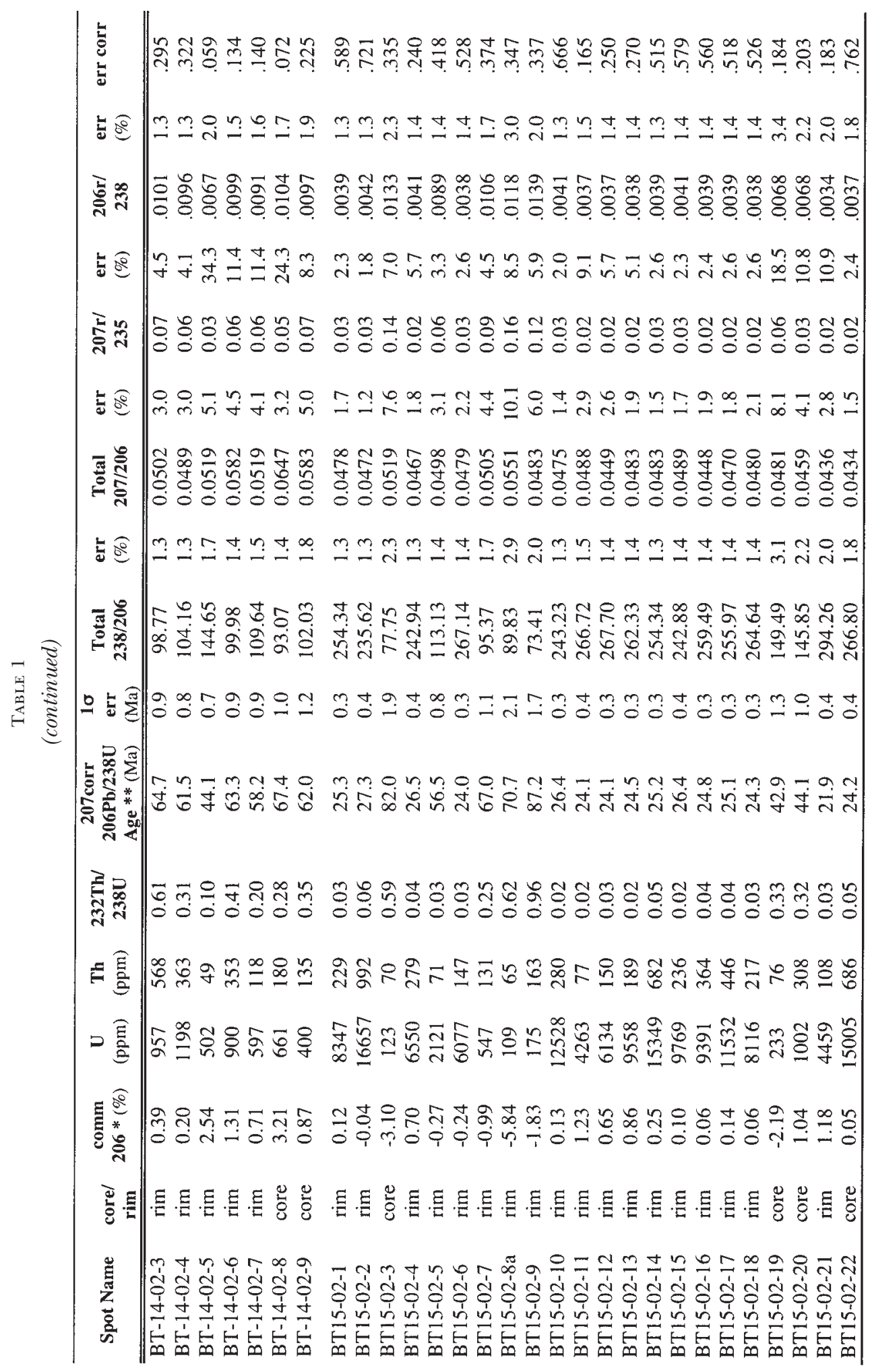




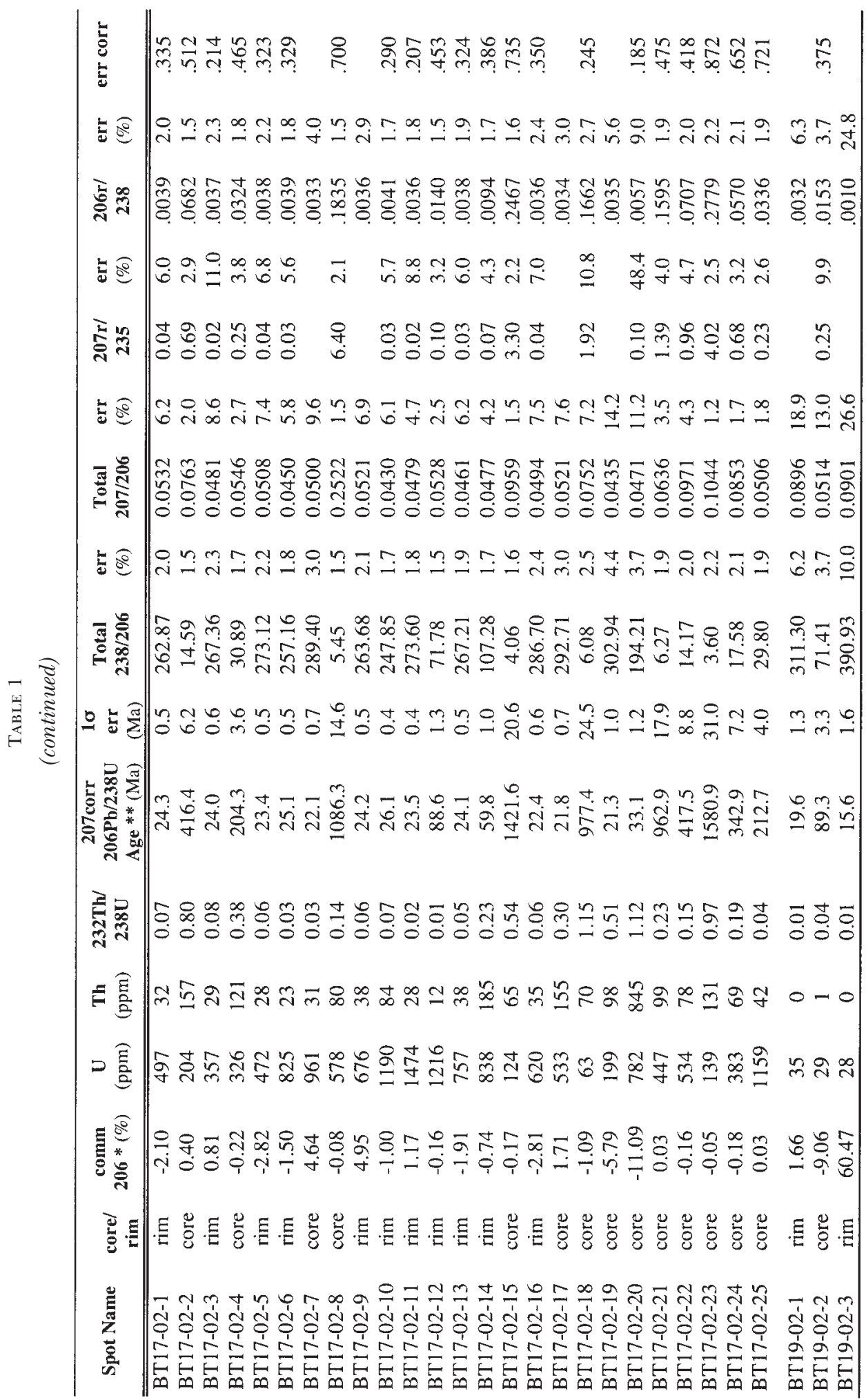




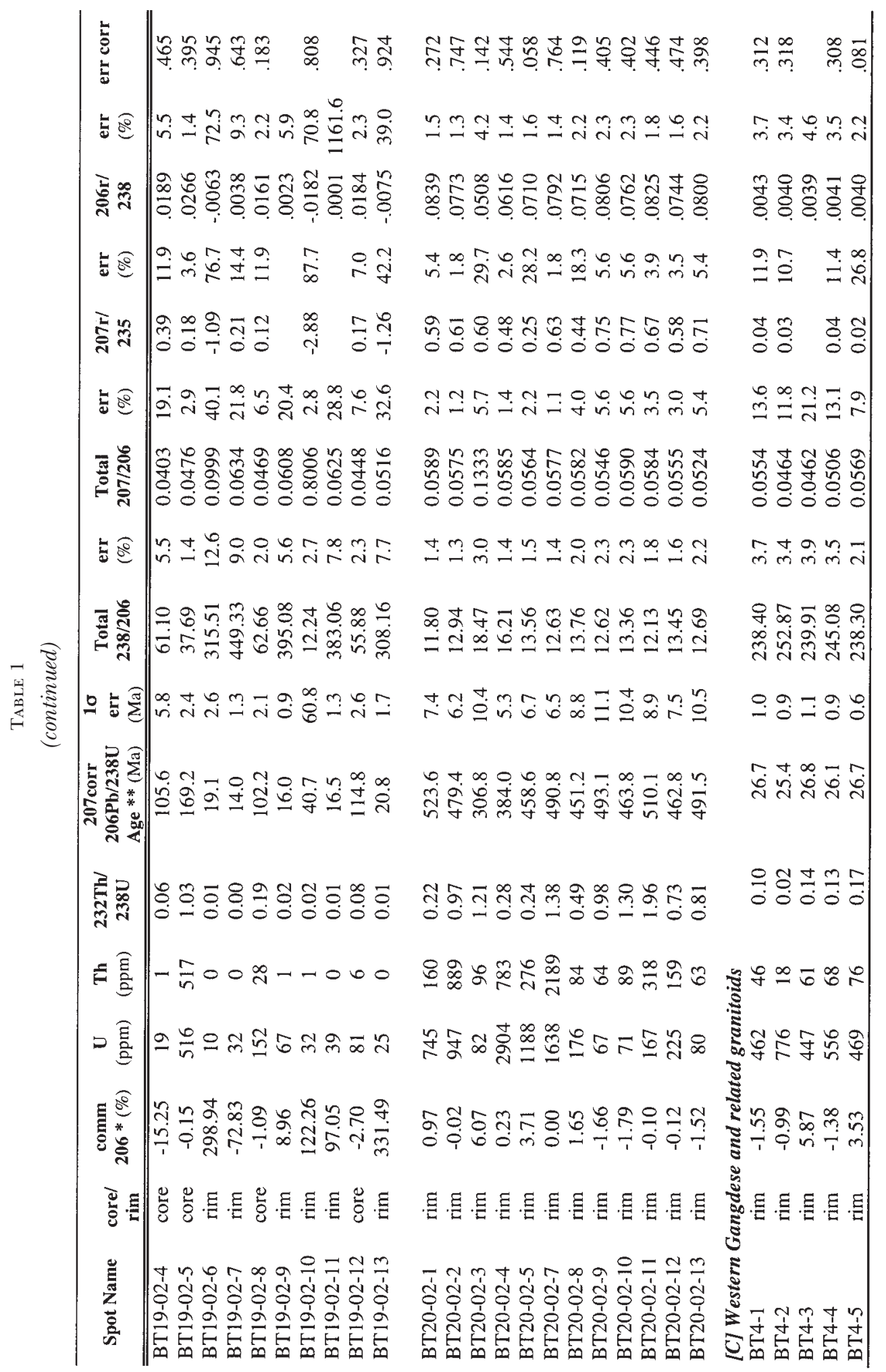




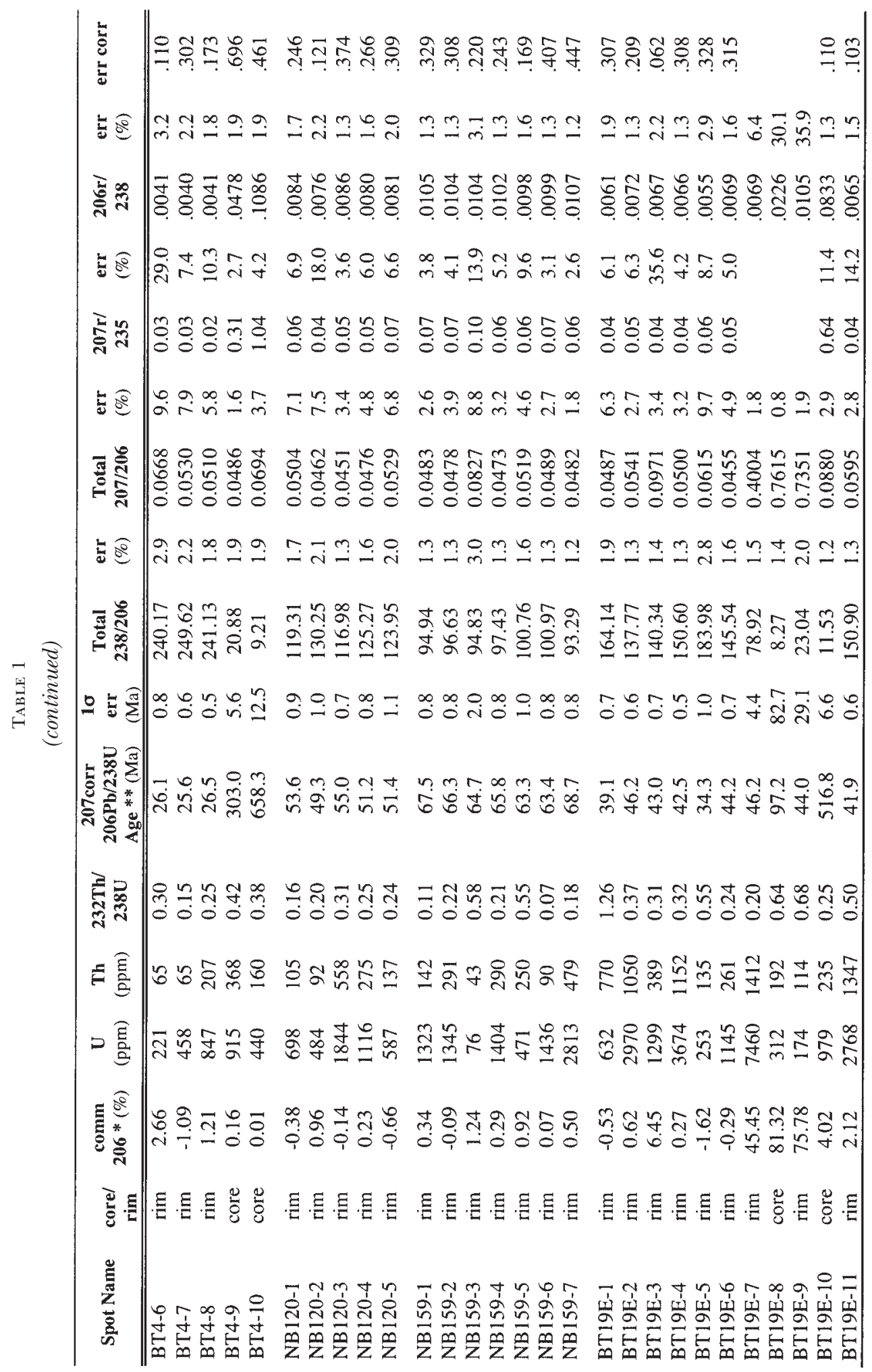




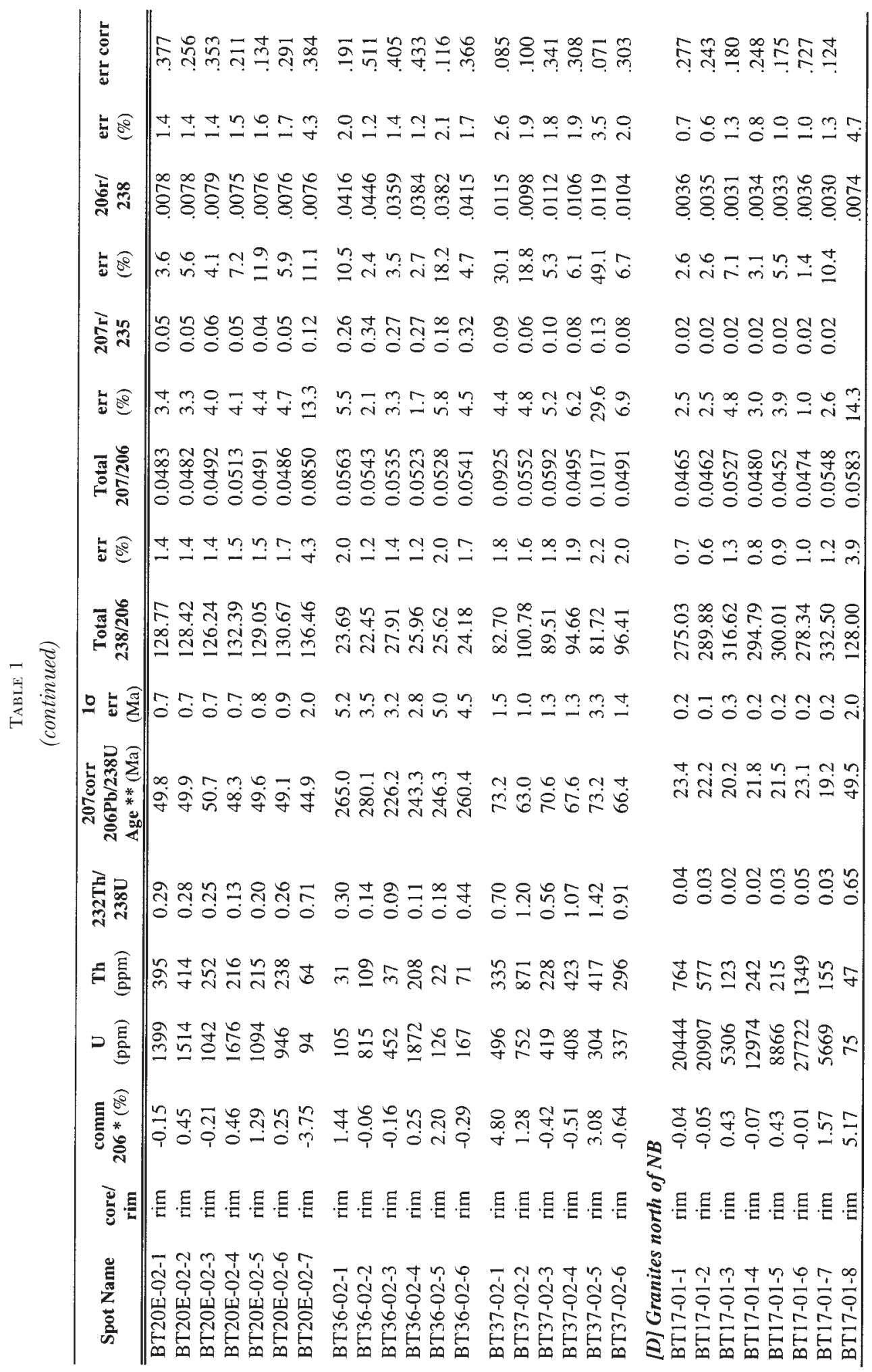




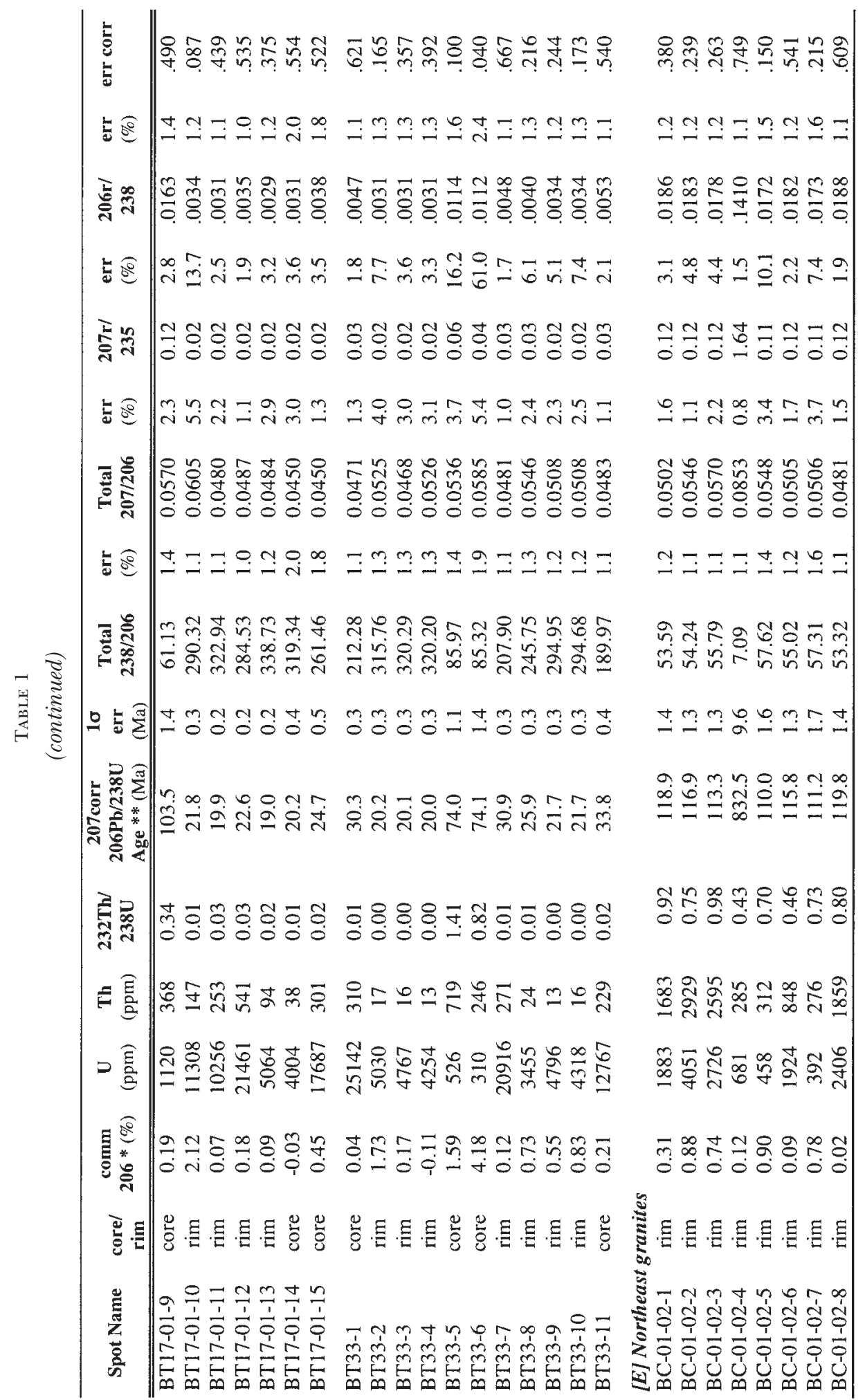




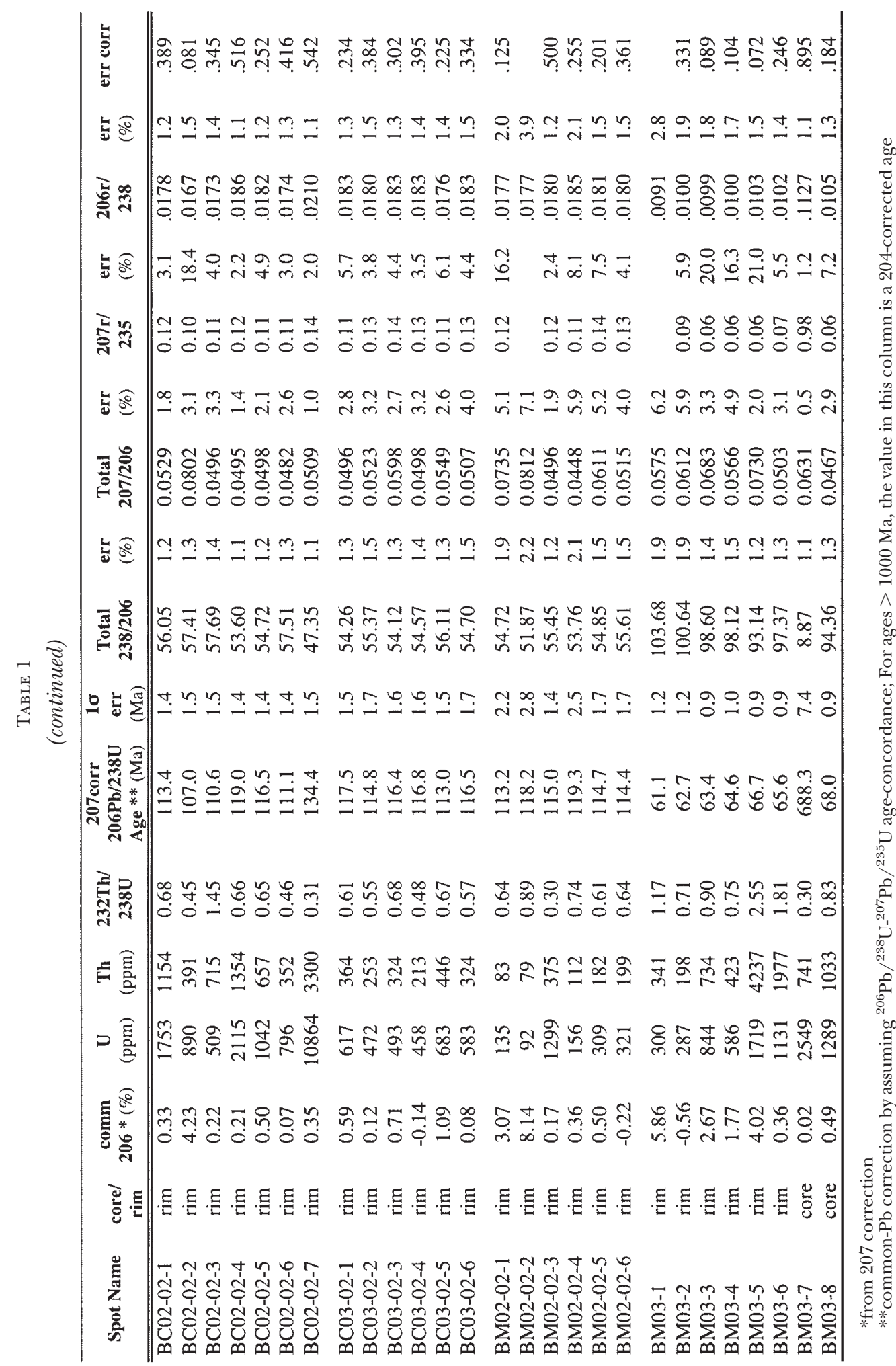



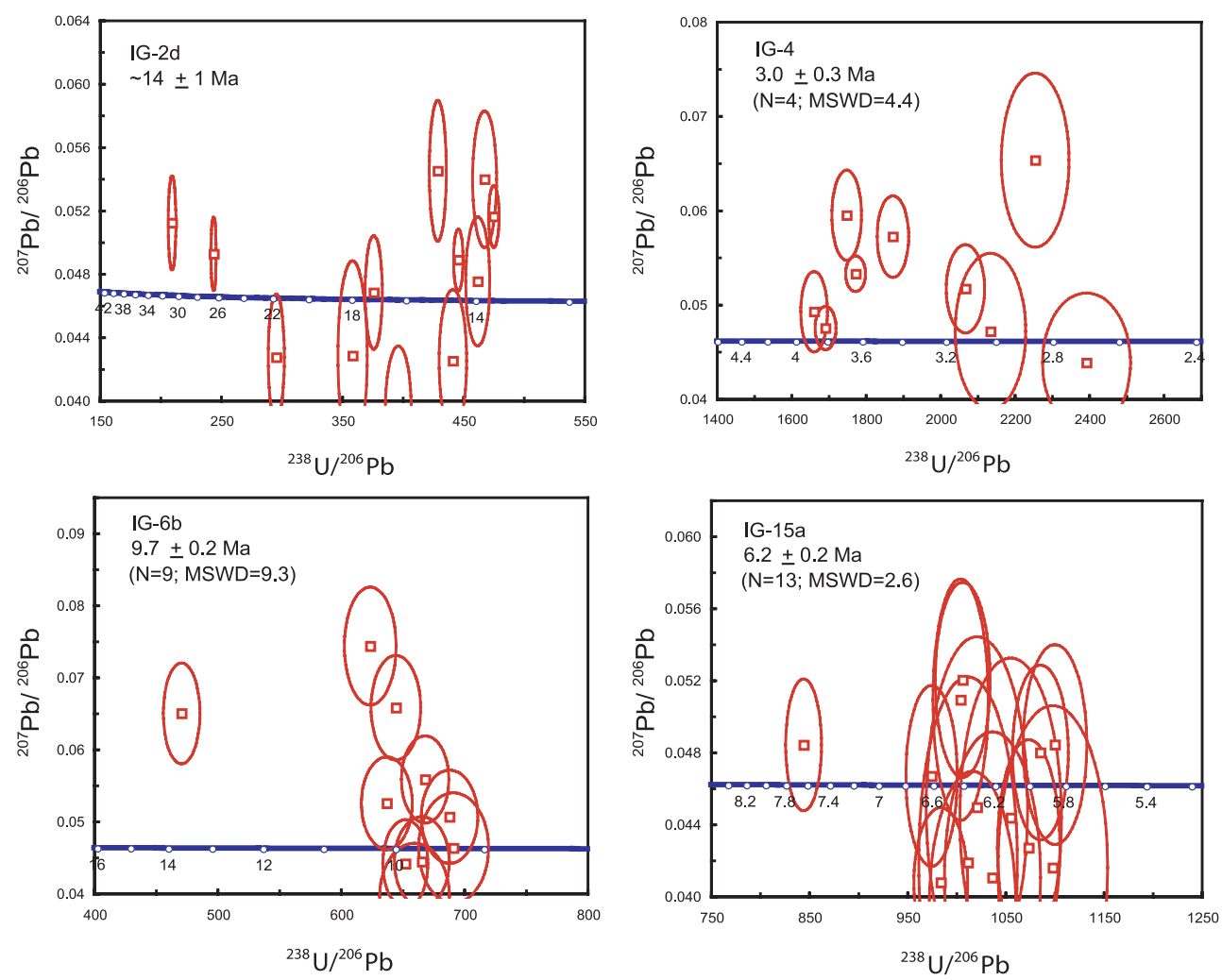

Fig. 7. Tera-Wasserburg concordia diagrams showing U-Pb SHRIMP ages for group A samples - from within the Namche Barwa massif. Error ellipses are shown at $2 \sigma$ uncertainty. Older zircon core ages are shown, where applicable, for all samples on composite Concordia plot.

range ( $5-8 \mathrm{Ma}) .13$ analyses comprised a coherent age group, with a weighted mean of $6.2 \mathrm{Ma}$. In sample IG-16, 9 rim spots and 4 core spots were analyzed. Of the $9 \mathrm{rim}$ ages, 6 comprised a coherent group with a weighted mean of $4.3 \mathrm{Ma}$. In sample IG-18, 9 rim spots and 10 core spots were analyzed. Some rim spots yielded ages as old as the cores, and many were discordant. Five rim ages, however, formed a coherent (young) age group with a weighted mean of 2.9 Ma.

[B] Along the northwestern margin of the NB-GP massif, the zircons are primarily Oligocene-Miocene in age (fig. 8), and were obtained from granitic bodies intruding both Lhasa block basement and Indian plate gneisses. Zircon core ages from this group show mostly Gangdese inheritance, except for sample BT-17, which exhibits protolith ages upwards of $1 \mathrm{Ga}$ (Lhasa block material). Sample BT-20 also exhibited a Pan-African zircon rim age of $465 \mathrm{Ma}$.

Rim age populations for samples BT-14, BT-15, BT-17, BT-19, BT-20 and NB-35 all contained a coherent group, from which the final age (weighted mean) was extracted. BT-07 did not yield a coherent group, so the final age is approximate and equals the average (40 Ma) of the three youngest analyses, which clustered between 38 and $42 \mathrm{Ma}$.

[C] West of the NB-GP massif, our results fall primarily into the age range of $\sim 40$ to $70 \mathrm{Ma}$ (fig. 9), with one $26 \mathrm{Ma}$ age observed in sample BT-4, collected near Nyingchi. Another anomalous age (250 Ma - late Permian) was observed in sample BT-36, farther to the west, between Bayi and Lhasa (not shown on map; 29 $58^{\prime} 23.0^{\prime \prime} \mathrm{N}$ 

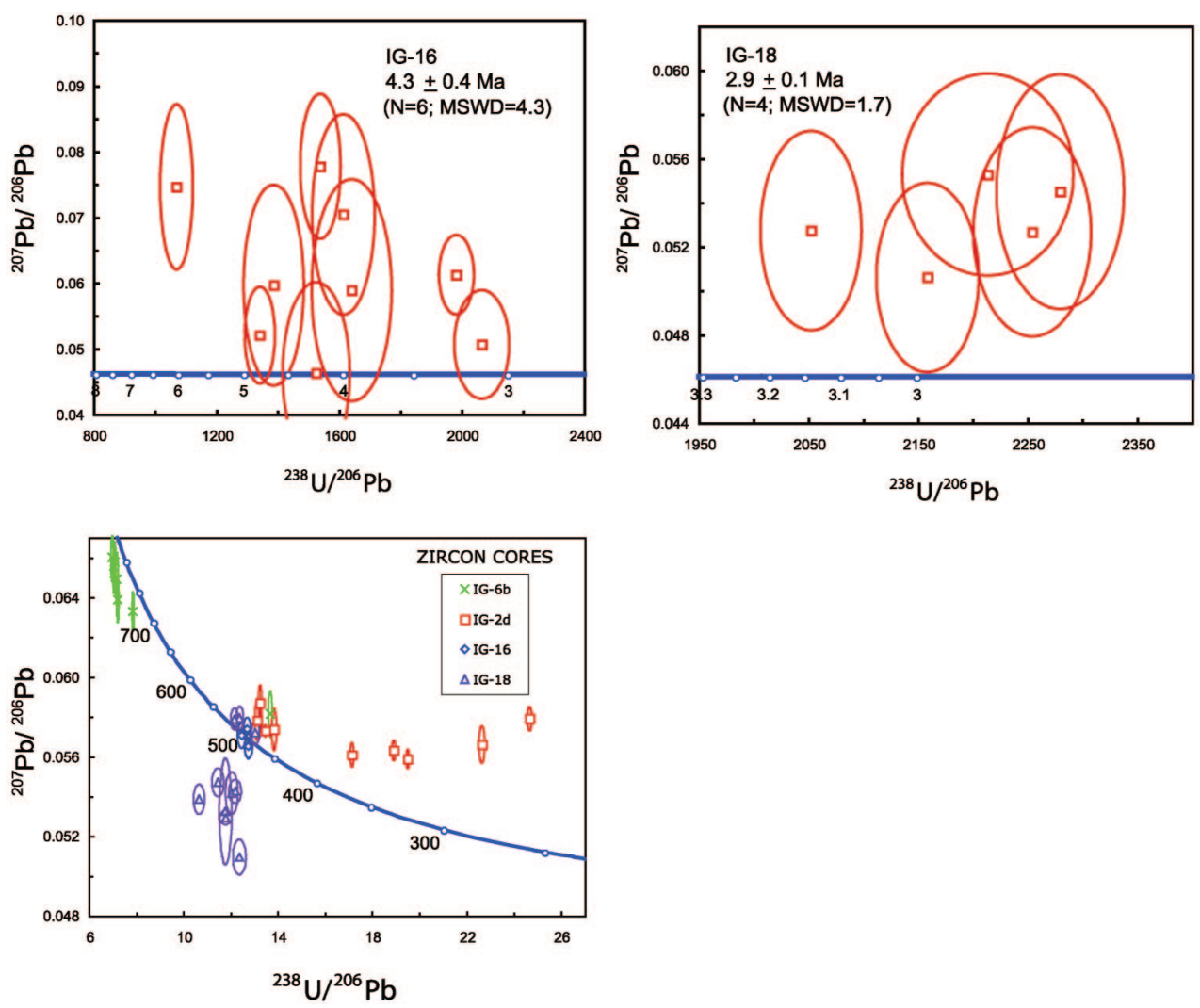

Fig. 7. (continued)

$\left.93^{\circ} 6^{\prime} 31.6^{\prime \prime} \mathrm{E}\right)$. Sample BT-37 is also off the map $\left(29^{\circ} 43^{\prime} 00.4^{\prime \prime} \mathrm{N} 93^{\circ} 2^{\prime} 22.4^{\prime \prime} \mathrm{E}\right)$, but yields a more-expected age of $72 \mathrm{Ma}$. Limited core ages for group $\mathrm{C}$ samples $(660 \mathrm{Ma}$ and $300 \mathrm{Ma}$ for BT-4; $520 \mathrm{Ma}$ and $97 \mathrm{Ma}$ for BT-19E) suggest a Gondwanan protolith, plus some mixing between core and rim compositions.

All Group C samples had rim age populations that yielded coherent groups. Final ages, presented on figure 9, represent the weighted means of each of these groups.

[D] Two samples, BT-17-01 and BT-33, collected north of Namche Barwa along the Jiali fault zone yield $21 \mathrm{Ma}$ ages (fig. 10). Core ages show evidence for a Gangdese protolith (74 Ma for BT-33; 100 Ma for BT-17-01). Rim ages for both samples exhibit a fair amount of scatter and did not possess a coherent age group; consequently these final ages are approximate. However, sample BT-17-01 shows a distinct cluster $(\mathrm{N}=11)$ of ages between 19 and $23 \mathrm{Ma}$, and BT-33 has a cluster $(\mathrm{N}=5)$ between 20 and $22 \mathrm{Ma}$, allowing us to place reasonably good constraints on these approximations.

[E] Northeast of Namche Barwa, in the vicinity of Bomi, the zircon populations are as old as Mesozoic (113 - $118 \mathrm{Ma}$ ) in age (fig. 11), with one $63 \mathrm{Ma}$ age. These samples (BM-02, BM-03, BC-01, BC-02, and BC-03) exhibited no distinct evidence of inheritance, and each age population yielded a coherent group. Final ages represent the weighted means of these coherent groups, and are expressed on figure 11.

Geochemistry. - All samples have bulk compositions within the range typical of peraluminous granites, consisting of quartz $(20-35 \%)$, plagioclase $(15-25 \%)$, K-feldspar (25-40\%), and muscovite \pm biotite (2-10\%). Namche Barwa (Group A) 

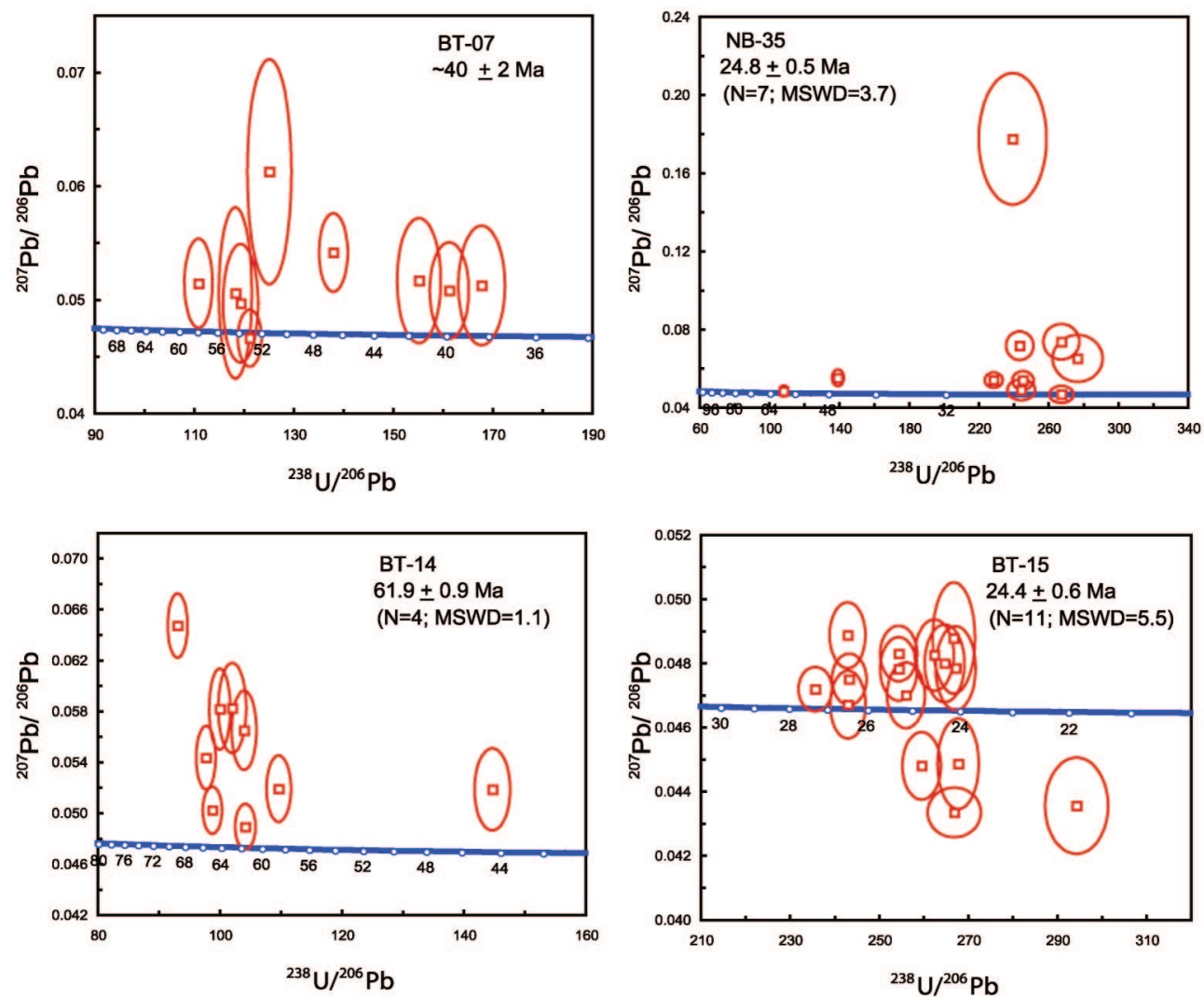

Fig. 8. Tera-Wasserburg concordia diagrams showing U-Pb SHRIMP ages for group B samples - from the northwest margin of the Namche Barwa-Gyala Peri massif. Error ellipses are shown at $2 \sigma$ uncertainty. Older zircon core ages are shown, where applicable, for all samples on composite Concordia plot.

granitoids are characterized by high silica content (table 2), with 70 to 79 weight percent $\mathrm{SiO}_{2}, \mathrm{Al}_{2} \mathrm{O}_{3}>12.0$ weight percent, and are metaluminous to slightly peraluminous (molar $\mathrm{Al}_{2} \mathrm{O}_{3} /\left(\mathrm{CaO}+\mathrm{Na}_{2} \mathrm{O}+\mathrm{K}_{2} \mathrm{O}\right)$ ratios between $\left.0.96-1.08\right)$. $\mathrm{Rb} / \mathrm{Sr}$ ratios are high for this group (fig. 12), relative to granitoids outside the massif, with an average ratio of 3.8. Granitic bodies outside of the massif, north and west of Gyala Peri and northeast of Namche Barwa (Groups B, C, D, and E), are predominantly peraluminous and have notably lower $\mathrm{Rb} / \mathrm{Sr}$ ratios.

Bulk geochemical abundances of the trace elements $\mathrm{Rb}, \mathrm{Y}$, and $\mathrm{Nb}$ indicate that the majority of the granites are calc-alkaline to alkaline, plotting in the field of volcanic arc granites (fig. 13) of Pearce and others (1984) and in the "post"-collision granite field of Pearce (1996).

\section{INTERPRETATION}

Our study encompasses a series of granitic bodies that vary in their geochemistry and emplacement age, and occur within differing tectonic terranes. These granitoids are grouped as follows: [A] those intruded into Indian gneisses of Namche Barwa; [B] intruded into Lhasa block and Indian plate metasediments along the northwest margin of the NB-GP massif; [C] Gangdese Arc and related granitoids intruded into Lhasa block metasediments considerably west of the NB-GP massif; [D] intruded into 

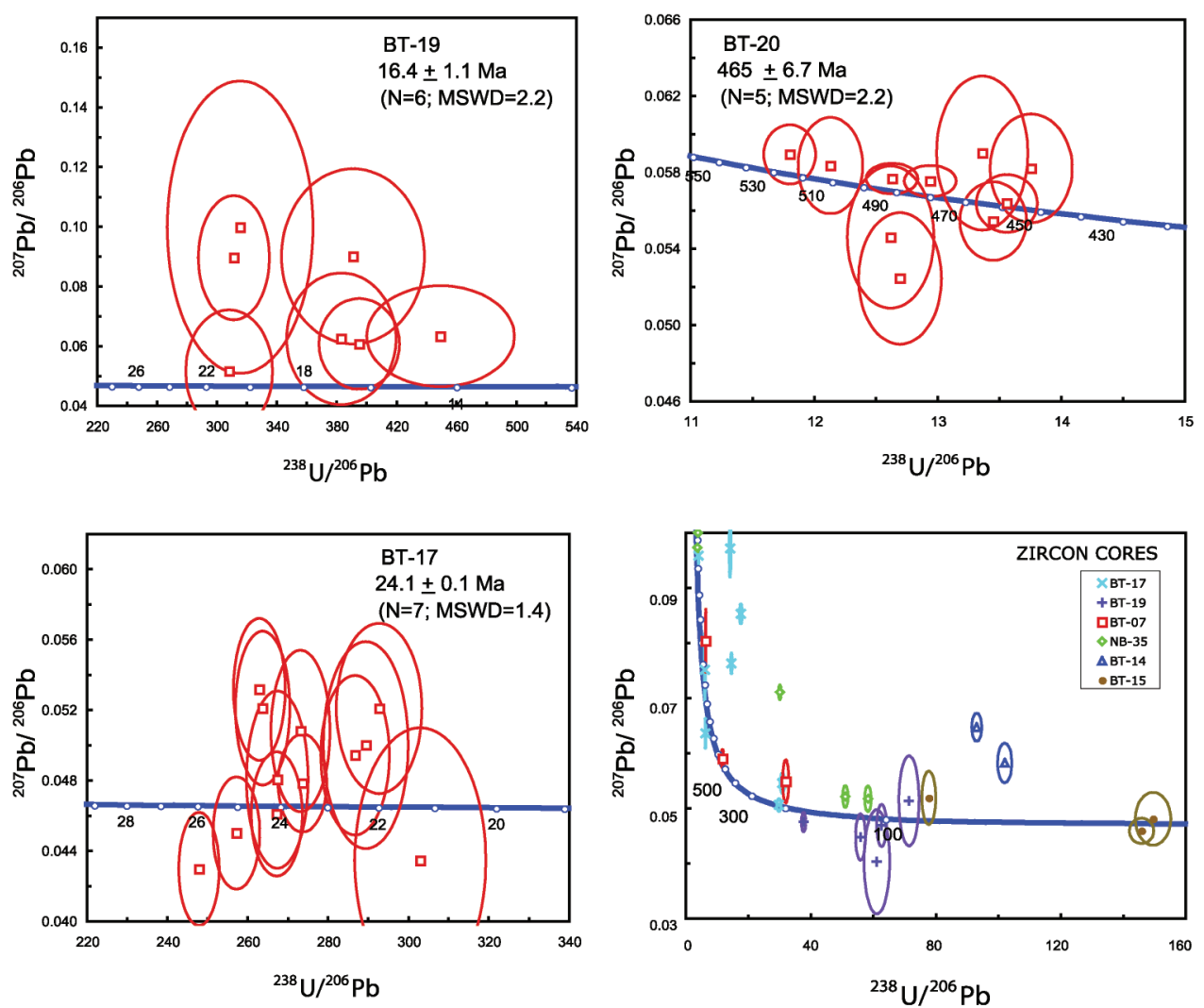

Fig. 8. (continued)

Lhasa block gneisses and metasediments north of Namche Barwa, near the Jiali fault zone; and [E] Gangdese Arc granitoids intruded into Lhasa block gneisses and metasediments northeast of Namche Barwa. We interpret the emplacement of these five groups of granites to be related to a series of different tectonic events impacting southeastern Tibet during Mesozoic-Cenozoic time.

Geochronology.-Our results for granite emplacement ages from Group A samples (Namche Barwa massif) are in good agreement with those reported by both Burg and others (1997) and Ding and others (2001), and support the evidence for exceptionally recent granitic activity near the massif core. Previously determined ages (Burg and others, 1997; Ding and others, 2001) combined with the results of this study define a distinct group of young crystallization ages for Namche Barwa massif samples. Also apparent is a well-defined population of 400 to 500 Ma core ages, possibly reflecting an event of regional high-grade metamorphism and melting during early Paleozoic time. Such evidence lends additional support to the concept of an early Paleozoic thrust event within Greater Himalayan rocks, as suggested by the studies of DeCelles and others (2000) and Gehrels and others (2003), and could indicate that Namche Barwa massif rocks may have undergone a similar history.

Group B samples (northwest margin of the NB-GP massif) contain protolith ages that help to delineate the ITSZ west of Gyala Peri. Within this transect across the suture (fig. 5), younger granitoids are present with ages of $24 \mathrm{Ma}$, but core ages indicate 

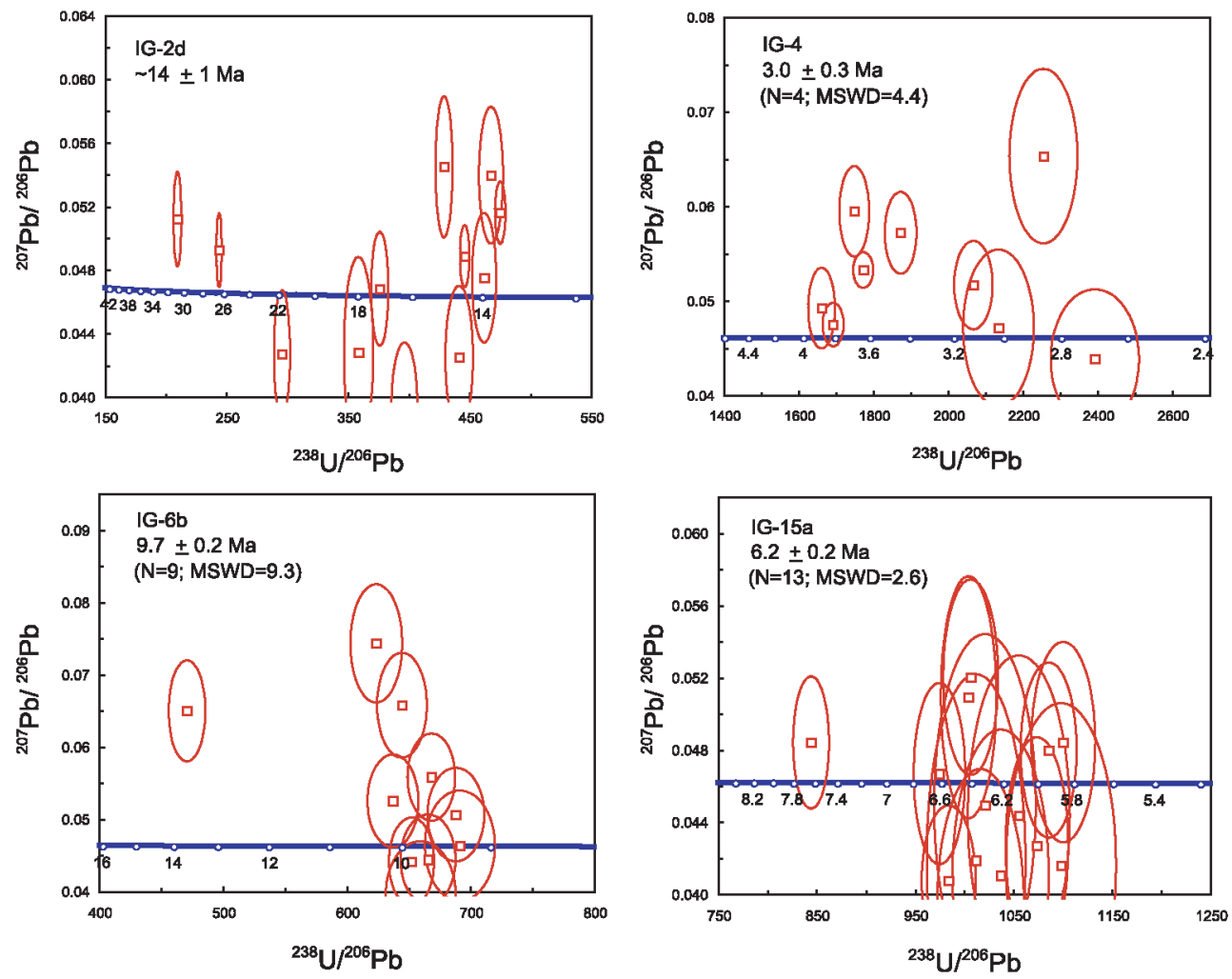

Fig. 9. Tera-Wasserburg concordia diagrams showing U-Pb SHRIMP ages from group C samples - from western Gangdese and Gandgese-related samples. Error ellipses are shown at $2 \sigma$ uncertainty. Older zircon core ages are shown, where applicable, for all samples on composite Concordia plot.

inherited signatures that jump sharply from Gangdese in the west (67 Ma for BT-14 and $82 \mathrm{Ma}$ for BT-15) to Indian in the east ("Pan-African" age of 465 for BT-20).

Group C samples (west of Namche Barwa) exhibit a cluster of crystallization ages between 40 to $70 \mathrm{Ma}$, corresponding to Gangdese plutonism. Sample BT-36, however, yielded a crystallization age of $250 \mathrm{Ma}$, which is not a surprising result, considering Permian rift-related rocks have been documented in the southern Lhasa block (Dewey and others, 1988).

Group E samples (northeast of Namche Barwa) contain numerous ages that correspond to Gangdese plutonism. Two isolated $21 \mathrm{Ma}$ ages (Group D) in the north, however, are too young to be related to this subduction-related magmatism. Considering the widespread documentation of magmatism along the Red River shear zone (for example, Leloup and Kienast, 1993; Zhang and Schärer, 1999), and partial melts with emplacement ages around 22 to $23 \mathrm{Ma}$, the $21 \mathrm{Ma}$ granitoids may be analogous to these melts. However, because these and similar other dikes consistently cut the ductile foliation of the gneisses in and near the Jiali fault zone, these granitic bodies are not likely to be a product of the shearing related to movement within this zone. Instead, we suggest they are perhaps related to the Gangdese Thrust event, which is of this age $(\sim 27-18 \mathrm{Ma})$ and involved underthrusting of part of the Gangdese belt (Copeland and others, 1995; Yin and others, 1999; Harrison and others, 2000). The role of the Gangdese Thrust, however, is controversial (that is, Aitchison and others, 2003). 

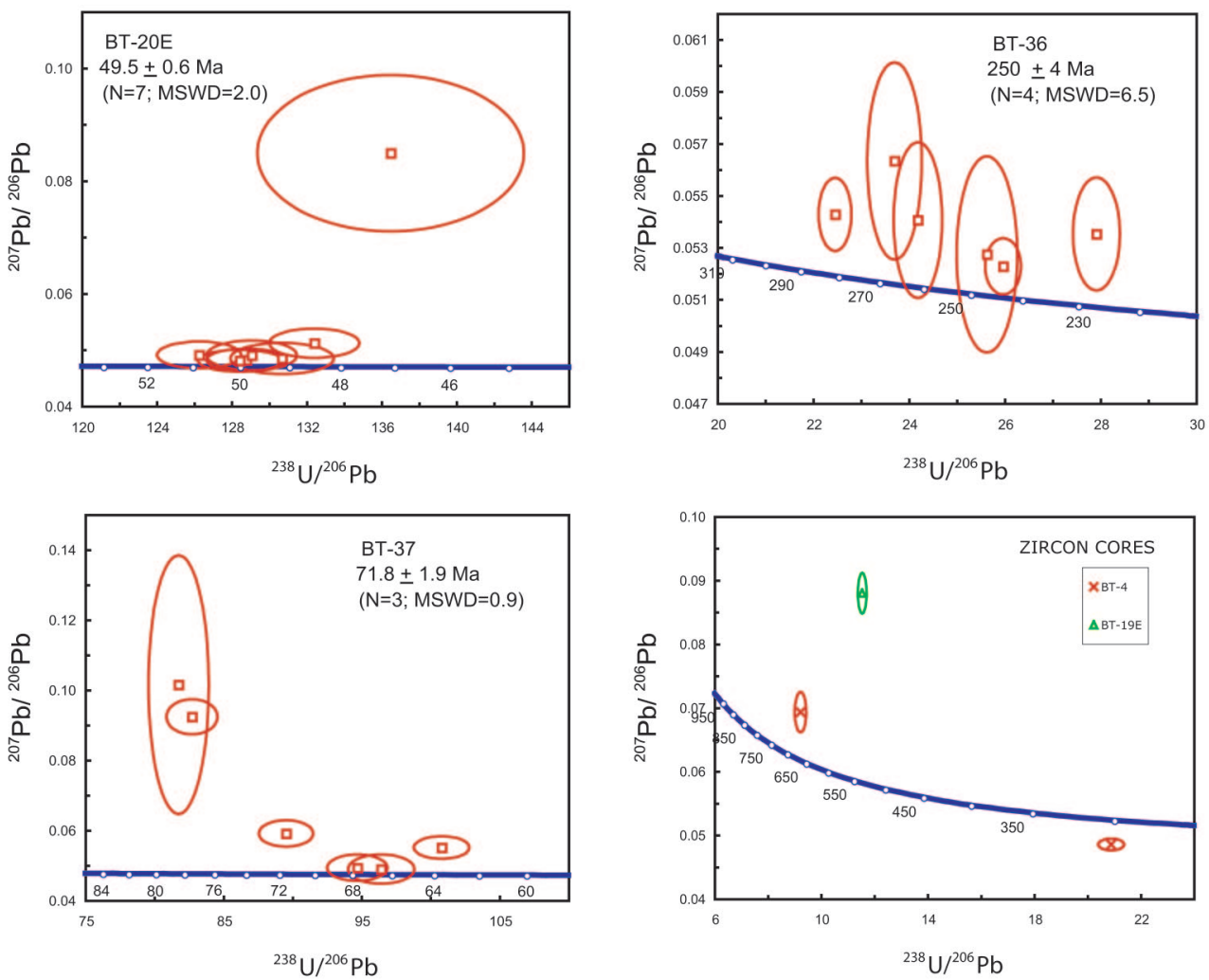

Fig. 9. (continued)

Therefore, an alternative means of production for the $\sim 21$ Ma granites might be slab break-off or slab detachment. Both of these mechanisms are suggested to have occurred at $\sim 25 \mathrm{Ma}$ (Kosarev and others, 1999; Miller and others, 1999; Chemenda and others, 2000; Yin and Harrison, 2000; Maheo and others, 2002; Kohn and Parkinson, 2002; Tilman and others, 2003).

Overall, in addition to the expected evidence for activity related to the Gangdese Arc, there is clear evidence in our results for a widespread partial-melting event around 20 to $25 \mathrm{Ma}$, and a much-younger (3 - $10 \mathrm{Ma}$ ) melting episode observed only at Namche Barwa. Geochemical data from the granites provides some insight as to the nature of these two young events.

Geochemistry.-Granitoids from within Namche Barwa exhibit a high $\mathrm{Rb} / \mathrm{Sr}$ ratio (greater than 1.4), with notably greater frequency than outside the massif (fig. 12). It has been shown (Harris and others, 1993; Whittington and others, 1999) that trace element abundances in granitic rocks can provide information regarding the conditions prevalent during melting. A study by Harris and Inger (1992) predicted the consequences of fluid-present and fluid-absent melting for the composition of pelitederived granites, in terms of the trace elements $\mathrm{Rb}, \mathrm{Sr}$ and $\mathrm{Ba}$. For granite systems, only these three elements reside predominantly in the major reactants and products of melting reactions (micas and feldspars). Concentration ratios $\left(\mathrm{C}_{\mathrm{l}} / \mathrm{C}_{\mathrm{o}}\right)$ in the liquid relative to the source are calculated from appropriate partition coefficients $\left(\mathrm{K}_{\mathrm{D}}\right)$ for granitic melts, using a range of values from Nash and Crecraft (1985), Blundy and 

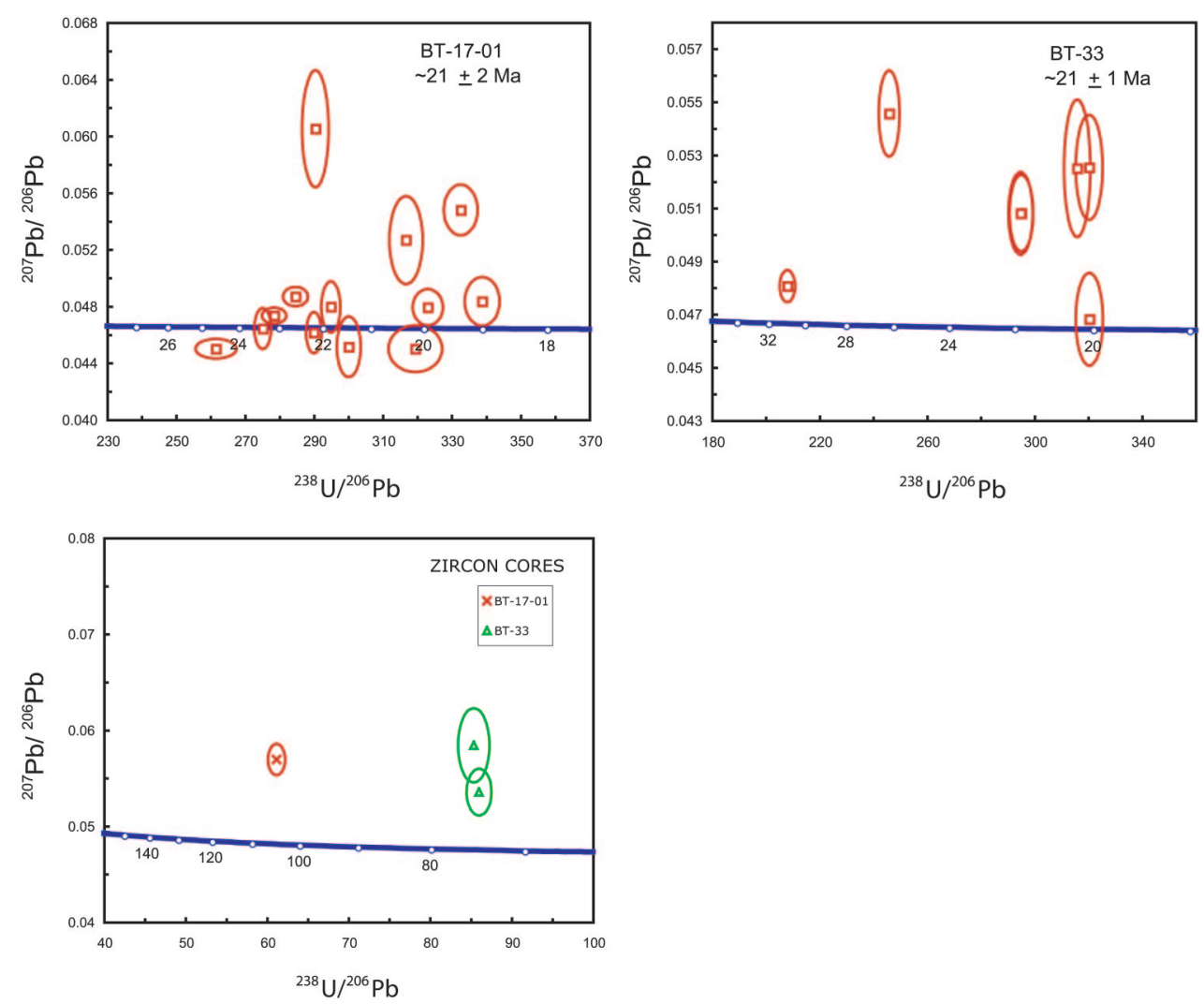

Fig. 10. Tera-Wasserburg concordia diagrams showing U-Pb SHRIMP ages for group D samples - from north of the Namche Barwa-Gyala Peri massif. Error ellipses are shown at $2 \sigma$ uncertainty. Older zircon core ages are shown, where applicable, for all samples on composite Concordia plot.

Wood (1991), and Harris and others (1993). Simple melts have well-defined $\mathrm{C}_{\mathrm{l}} / \mathrm{C}_{\mathrm{o}}$ ratios for $\mathrm{Rb}, \mathrm{Sr}$ and $\mathrm{Ba}$, whether controlled by mineral fractionation or by partial melting (Whittington and others, 1999). Fluid-present melting results in low $\mathrm{Rb} / \mathrm{Sr}$ ratios and depleted $\mathrm{Ba}$ relative to the source, whereas fluid-absent melting results in high $\mathrm{Rb} / \mathrm{Sr}$ ratios and enrichment of Ba. Geochemical modeling of $\mathrm{Rb}$ and Sr during anatexis suggests that fluid-absent breakdown of muscovite would produce melts with $\mathrm{Rb} / \mathrm{Sr}$ ratios $>1.5$ (Harris and Inger, 1992).

The majority of the Namche Barwa samples (group A) exhibit relatively high $\mathrm{Rb} / \mathrm{Sr}$ ratios (>1.4) suggesting that a fluid-absent melting (decompression) regime dominates near the massif core. Meanwhile, granitoids from groups B, C, D and E exhibit $\mathrm{Rb} / \mathrm{Sr}$ ratios consistently below 1.5 (table 2 ) and imply fluid-present melting in these surrounding regions.

A particularly interesting result is that the Namche Barwa granites with the youngest U-Pb zircon ages (3.0 Ma and 2.9 Ma, samples IG-4 and IG-18) exhibit a low $\mathrm{Rb} / \mathrm{Sr}$ ratio, implying a fluid-present melting history. This result has implications for both the rate of melt emplacement and the degree of meteoric water circulation at Namche Barwa. Moreover, the presence of both fluid-absent and fluid-present melts is significant, as it resembles conditions at Nanga Parbat in the western Himalayan syntaxis. At Namche Barwa, the predominance of fluid-absent "decompression" melts 

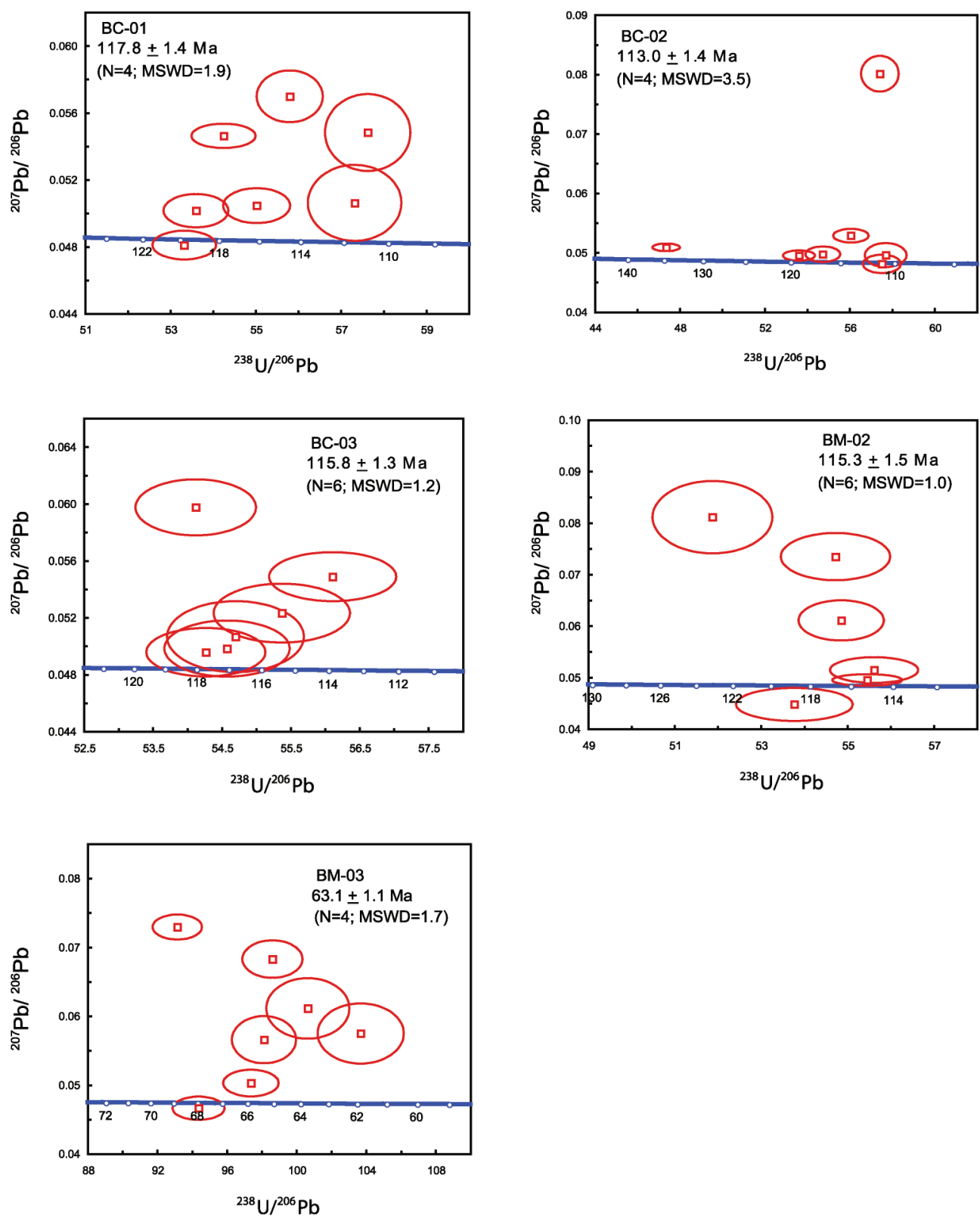

Fig. 11. Tera-Wasserburg concordia diagrams showing U-Pb SHRIMP ages for group E samples - from the area of Bomi, northeast of the Namche Barwa-Gyala Peri massif. Error ellipses are shown at $2 \sigma$ uncertainty.

could be a reflection of numerous varying parameters: (1) the sample locality bias-it is considerably more difficult to collect samples from the core of the massif as opposed to the lower-elevation flanks; (2) the uplift rate-if it were sufficiently rapid everywhere, only rarely could assemblages be preserved that were allowed to cool above the wet pelite solidus; (3) the degree of meteoric fluid circulation-how deep and how 


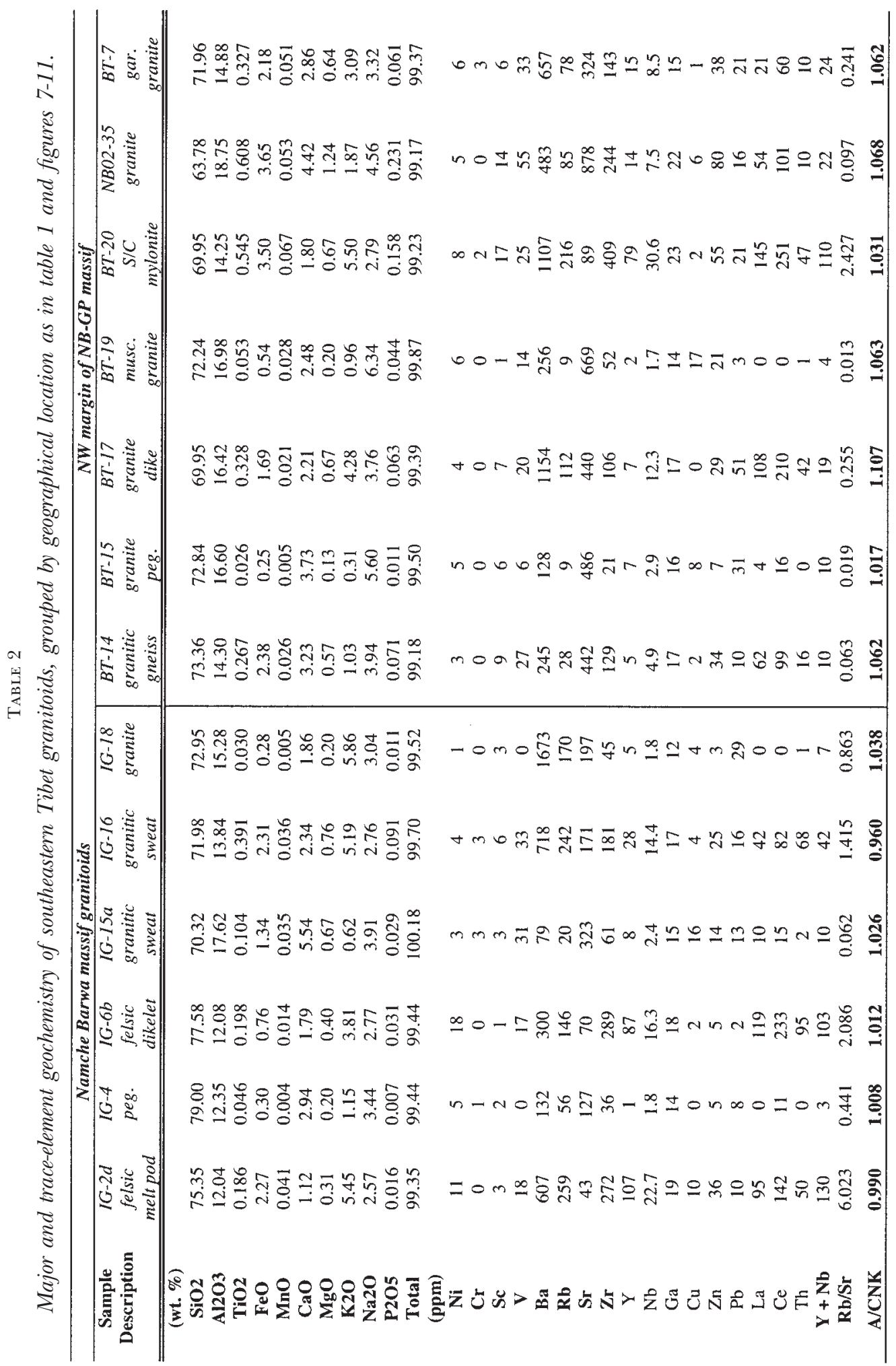




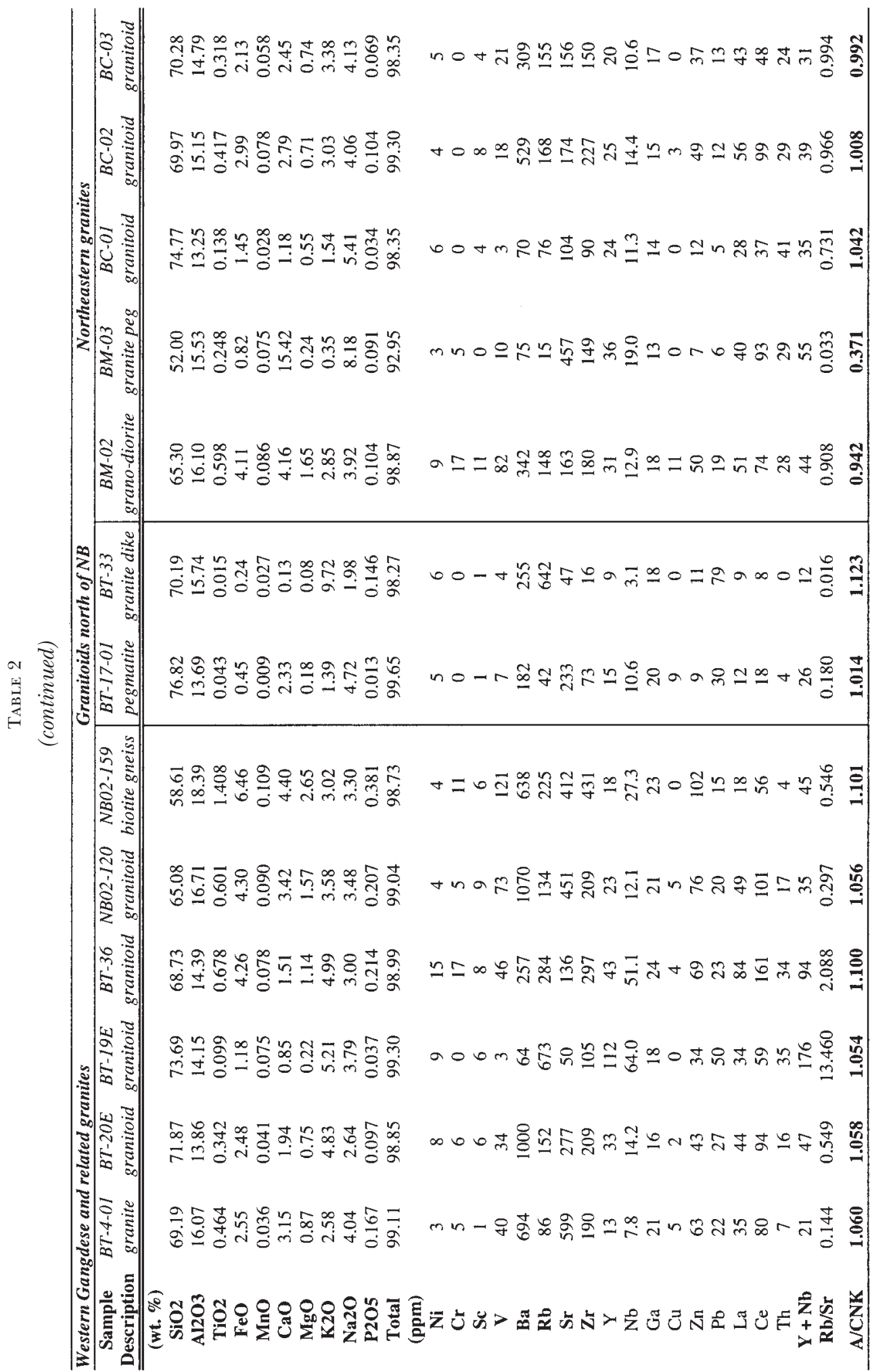




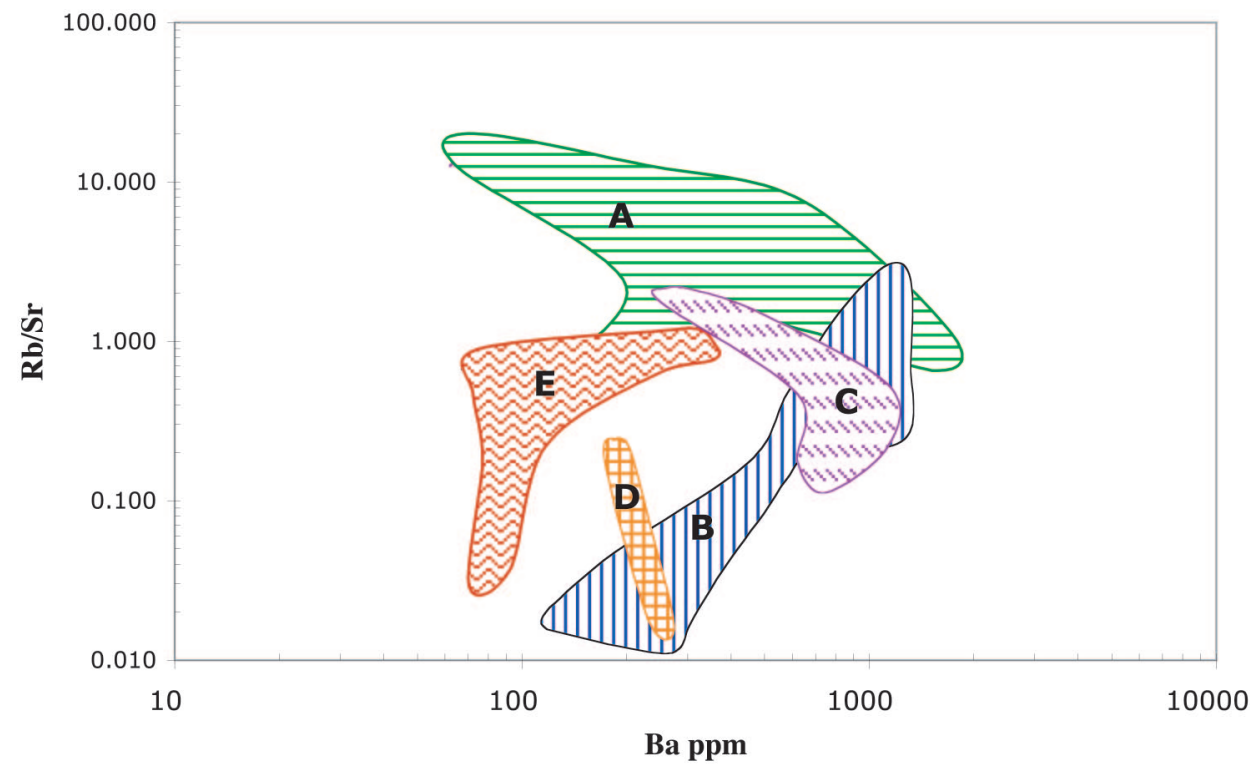

Fig. 12. Rb/Sr ratio vs. Ba (ppm) plot, showing the geochemical variation among sample groups. Fields labeled by geographic grouping: (A) Namche Barwa massif granitoids (green horizontal lines), (B) NW margin of NB-GP massif granites (blue vertical lines), (C) western Gangdese and related samples (purple diagonal dashes), (D) Northern granites (orange crosshatch pattern), and (E) northeastern/Bomi region granitoids (red wavy lines), data from table 2 . Note the higher frequency of decompression melts $(\mathrm{Rb} / \mathrm{Sr}$ ratios $>1.4$ ) among the group A (Namche Barwa) granite suite.

extensively meteoric water has pervaded the crust; (4) the level of metamorphism previously experienced by rocks entering the massif-if they were low-grade and fertile, fluid-present melting would dominate, as opposed to Nanga Parbat, where rocks had undergone earlier high-grade metamorphism and were entering the massif relatively dry; or (5) deformation coeval with emplacement of melts, enhancing fluid infiltration-some samples show clear evidence of syn-kinematic emplacement and foliation.

Tectonic discrimination of granites. - Southeastern Tibet is tectonically complex, but trace-element modeling provides constraints on the dominant tectonic regime that is reflected in the geochemistry of granitic melts. Trace-element geochemical analyses indicate that the majority of the granites are calc-alkaline to alkaline, plotting in the field of volcanic arc granites (fig. 13) of Pearce and others (1984) and in the "post"-collision granite field of Pearce (1996). Pearce (1996) emphasized that the collisional granites are the most difficult to classify on the basis of chemistry, as they have the greatest range of sources. Unlike granites from other settings, collisional granites cannot be explained and modeled by their trace element geochemical behavior, in terms of a single, well-defined mantle or crustal source. They can result from melting of the upper mantle due to adiabatic decompression that accompanies collisional uplift and erosion (England and Thompson, 1984), and might plot in either the volcanic arc or the within-plate field. In southeastern Tibet, volcanic arc activity is clearly present north of the Namche Barwa syntaxis, but within the massif itself the source of the melts is more ambiguous. Young zircon ages $(<10 \mathrm{Ma})$ in the context of a $60 \pm 10 \mathrm{Ma}$ Himalayan orogeny require that these melts are not related to early thrusting and crustal thickening/shortening. The presence of decompression melts in a region that is being exhumed rapidly is also characteristic of later stages of collisional 

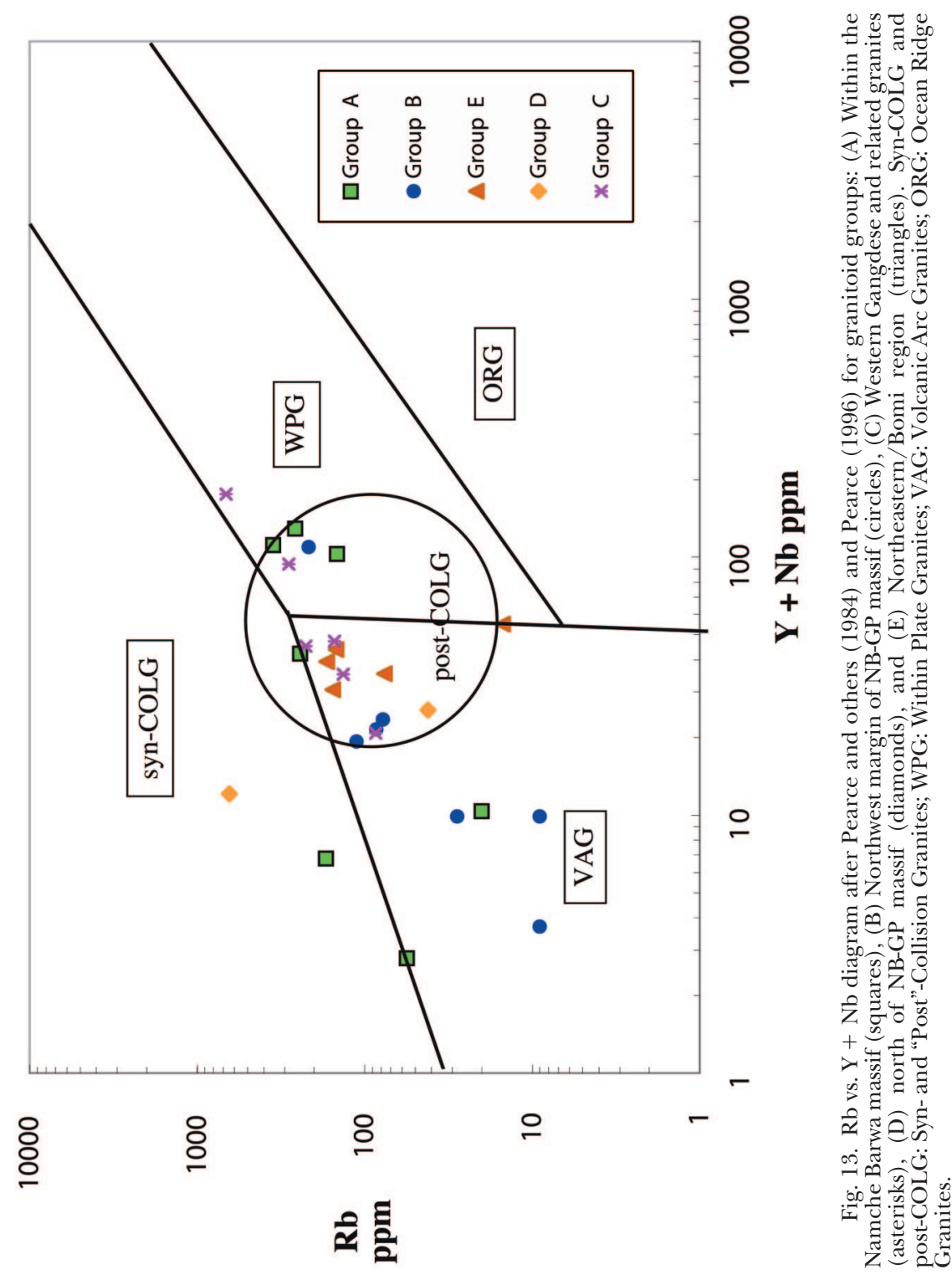
tectonic settings. Hence, the distribution of Namche Barwa granites on Pearce and others' (1984) tectonic discrimination diagram, spanning the volcanic arc and within plate fields, is in accordance with our other data sets, specifically zircon ages, $\mathrm{Rb} / \mathrm{Sr}$ geochemistry and geological and tectonic settings.

Zircon core ages provide further constraints on the source area for these granitoids. For group A samples, U-Pb ages of predominantly 400 to $500 \mathrm{Ma}$, with some 700 to $800 \mathrm{Ma}$ ages (table 1) imply an Indian plate precursor for the youngest melts. Outside of Namche Barwa, most core ages are greater than $500 \mathrm{Ma}$, with the oldest protolith ages $(0.9-2.4 \mathrm{Ga})$ present in the northern and western granite groups. Lhasa block material is the most likely source for these granites, but older metasediments or Indian continental basement cannot be ruled out on this basis alone.

\section{DISCUSSION}

Namche Barwa granites. - The granites from Namche Barwa exhibit zircon U-Pb ages consistently under $10 \mathrm{Ma}$ and thus are distinct from those reported elsewhere in the Himalayas. The young ages correspond to a period of rapid denudation at Namche Barwa, estimated at $\sim 10 \mathrm{~mm} / \mathrm{yr}$ over the last 4 Myr (Burg and others, 1997). Coincidence of young granites with a period of rapid erosion suggests a cause-effect relationship, in particular a scenario involving decompression melting that mimics Nanga Parbat in the western Himalayan syntaxis. Relatively high $\mathrm{Rb} / \mathrm{Sr}$ ratios in the Namche Barwa granites support a decompression melting regime similar to Nanga Parbat, where rapid exhumation has led to leucogranite emplacement by fluid-absent breakdown of muscovite (Zeitler and Chamberlain, 1991; Butler and others, 1997; Whittington and others, 1999). Young activity and decompression melts are evidence in favor of a "tectonic aneurysm" model (Zeitler and others, 2001a; Koons and others, 2002), attributing anatexis and high-grade metamorphism to rapid exhumation by the Yalu Tsangpo.

Coupled thermal-mechanical-erosional modeling (Koons and others, 1998; Zeitler and others, 2001b; Koons and others, 2002) shows that in a deforming orogen, local rheological variations will arise from deep and rapid incision. The crust will weaken as the strong upper crust is stripped from above by erosion and the local geotherm is steepened from below by rapid uplift of hot rock. If this process occurs where the crust is already weak, it will focus local upward movement of material from below. Provided that efficient erosion continues, a positive feedback develops in which flow of material into this weakened zone maintains local elevation and relief, reinforcing the concentrated exhumation and bowing up isotherms, further weakening the upper crust. This focusing of strain and rapid exhumation leads to metamorphic and structural overprinting of the crust as high-temperature lower crustal rocks are isothermally decompressed, and also leads to development of large mountains of limited spatial extent perched atop hot, weak crust. It is this concentration of exhumation and redirection of strain, with associated thermal, petrological, and geophysical anomalies, that Zeitler and others (2001a) dubbed a "tectonic aneurysm," in the sense of self-sustained failure of a normally strong boundary. Inherent in this model is the notion that feedback can amplify rather local geomorphic processes to the point where they exert a profound influence on the metamorphic and structural evolution of rocks at considerable depth. The emplacement of young melts near the core of Namche Barwa seems to support this model.

Granites outside Namche Barwa.-Zircon core and rim ages from the E-W transect across the western margin of Gyala Peri confirm the location of the suture zone between Indian and Asian plate components. Paralleling the trend of several other geological units and foliations, the attenuated suture wraps around just to the west of the Gyala Peri massif. West of Gyala Peri, U-Pb ages of samples intruding Lhasa Block basement exhibit a distinct cluster within 40 to $70 \mathrm{Ma}$, corresponding to Gangdese 
plutonism. However, the younger $(<26 \mathrm{Ma})$ group in this area must be associated with a more recent metamorphic event, possibly related to slip along the Gangdese thrust, slab break-off, or slab detachment. Neogene magmatism in the Gangdese belt is uncommon but has been identified in several places, with calc-alkaline magmatism of Gangdese geochemical affinity documented at 18 to $16 \mathrm{Ma}$ in southwestern Tibet (Miller and others, 1999) and at 16 to $10 \mathrm{Ma}$ in south-central Tibet (Coulon and others, 1986). Samples BT-4, NB-35-02, BT-15, and BT-17 all yield U-Pb zircon ages between 24 to $26 \mathrm{Ma}$, but do not exhibit a decompression melt signature and are therefore unlikely to be related to an eastward continuation of the STDS. These samples do, however, show volcanic arc affinity as per Pearce and others (1984) and might represent young Gangdese-related magmatism. Harrison and others (2000) proposed that a continuous process produced calc-alkaline Gangdese magmatism through the Tertiary, caused by an input of heat from the asthenosphere. Through such a mechanism, our 24 to 26 Ma granites could have been produced as collisional melts, representing continued subduction of Indian lithosphere (Chung and others, 2003). Alternatively, slab break-off of the subducting Indian continental margin, or slab detachment, whereby the mantle lithosphere peels off from the overlying crust and passively sinks into the asthenosphere, might explain the origin of these magmas. Yet another possibility is that processes related to underthrusting on the Gangdese Thrust structure, such as dewatering or shear heating, contributed to production of these $\sim 25$ Ma granites.

The two 21 Ma samples from north of Namche Barwa (BT-33, BT-17) along the Jiali fault zone are distinct from the 24 to 26 Ma group north and west of Gyala Peri, based on their tectonic setting and geochemistry. These granites might be related to Miocene shearing as reported for the Red River fault (Schärer and others, 1990, 1994; Harrison and others, 1992; Leloup and Kienast, 1993; Leloup and others, 1993, 1995). Although the Red River fault is located considerably southeast of the eastern Himalayan syntaxis, it was at that time a left-lateral fault, possibly related to the ductile sinistral shear seen near Tungmai on the Jiali fault zone. An eastern extension of the Jiali-Parlung fault is reported to have been dextrally active during $\sim 18$ to $12 \mathrm{Ma}$ (Lee and others, 2003), and perhaps the associated shear produced the 21 Ma granites that we observe. Common syntectonic emplacement of granitic melts in ductile strike-slip shear zones can be explained by partial melting of the lower crust, induced by shear heating in the upper mantle (for example, Leloup and others, 1999). If this is the case, samples BT-33 and BT-17 represent westward manifestations of the early Miocene oblique-slip tectonics and shear heating regime more prominent in easterly parts of the Tibetan-Himalayan orogen.

Another possible cause of Oligo-Miocene igneous activity in southern Tibet suggested by Yin (2000) is lithospheric-scale rifting, whereby large, deep cracks in the mantle lithosphere allow asthenosphere to flow upward, providing the necessary heat for melt production. Alternatively, the $\sim 21$ Ma granites could be related to slab break-off, slab detachment, or a Gangdese Thrust event, similar to the 24 to $26 \mathrm{Ma}$ granites further southeast.

\section{CONCLUSION}

Our U-Pb SHRIMP ages establish a complex tectonic history for southeastern Tibet, with the presence of at least five magmatic episodes: 400 to $500 \mathrm{Ma}, \sim 120 \mathrm{Ma}, 40$ to $70 \mathrm{Ma}, 18$ to $25 \mathrm{Ma}$, and 3 to $10 \mathrm{Ma}$. The oldest age group is attributed to early Paleozoic tectonism. Later melting episodes are primarily related to the CretaceousTertiary India-Asia convergence and collision, including the subduction of Neo-Tethys oceanic crust and Gangdese plutonism. Less expected, however, is the widespread occurrence of 20 to 25 Ma granitoids in the areas surrounding the Namche Barwa massif. These could be a product of slab break-off, slab delamination, Gangdese 
thrusting, or early Miocene shearing accompanying dextral motion along the Jiali fault.

The youngest group (3 - $10 \mathrm{Ma})$ of granitoids, present within the core of the Namche Barwa massif along and near the Yalu Tsangpo gorge, provides solid evidence for a tectonic-surficial feedback relationship at Namche Barwa. Geochemical data indicates the presence of young granites produced by both fluid-absent and fluidpresent melting in the Namche Barwa and adjacent regions, with a decompression melting regime dominating in the core of the Namche Barwa massif. Taken together, our geochronologic and geochemical data appear to support a tectonic aneurysm model for the development of Namche Barwa. Surrounding the Namche Barwa-Gyala Peri massif, however, granite emplacement results from distinctly different modes of production. This mode of production reflects the complex deformation at the eastern edge of the Indian plate, and the recent (Miocene and younger) activity along warped eastward expressions of dominant Himalayan structures.

\section{ACKNOWLEDGMENTS}

We thank Peter Blisniuk, George Gehrels, and An Yin for constructive reviews. This research was supported by grants from the National Science Foundation Continental Dynamics Program in support of the Namche Barwa Project, 'Geodynamics of Indentor Corners' (EAR-0003530-002). We thank colleagues at the Chengdu Institute of Geology and Mineral Resources for indispensable help with logistics and fieldwork, and for discussions and information about the geology of the area. Jacob Waldbauer and Travis Horton provided essential help with the SHRIMP-RG analyses.

\section{REFERENCES}

Aitchison, J. C., Davis, A. M., Badengzhu, and Luo, H., 2003, The Gangdese thrust: a phantom structure that did not raise Tibet: Terra Nova, v. 15, p. 155-162.

Blundy, J. D., and Wood, B. J., 1991, Crystal-chemical controls on the partitioning of Sr and Ba between plagioclase feldspar, silicate melts, and hydrothermal solutions: Geochimica et Cosmochimica Acta, v. 55, p. 193-209.

Burchfiel, B. C., King, R., Royden, L. H., Wang, E., Chen, Z., Zhang, X., and Zhao, J., 1998, Tectonic interpretation of GPS results from the SE part of the Tibetan Plateau and within the European/Asian framework: Abstracts with Programs - Geological Society of America, v. 30, p. 108.

Burg, J. P., Davy, P., Nievergelt, P., Oberli, F., Seward, D., Diao, Z., and Meier, M., 1997, Exhumation during crustal folding in the Namche Barwa syntaxis: Terra Nova, v. 9, p. 53-56.

Burg, J. P., Nievergelt, P., Oberli, F., Seward, D., Davy, P., Maurin, J. C., Diao, Z., and Meier, M., 1998, The Namche-Barwa syntaxis: Evidence for exhumation related to compressional crustal folding: Journal of Asian Earth Sciences, v. 16, p. 239-252.

Butler, R. W. H., Harris, N. B. W., and Whittington, A. G., 1997, Interactions between deformation, magmatism and hydrothermal activity during active crustal thickening: a field example from Nanga Parbat, Pakistan Himalayas: Mineralogical Magazine, v. 61, p. 37-52.

Chemenda, A. I., Burg, J. P., and Mattauer, M., 2000, Evolutionary model of the Himalaya-Tibet system: geopoem: based on new modelling, geological and geophysical data: Earth and Planetary Science Letters, v. 174, p. 397-409.

Chung, S. L., Lo, C. H., Lee, T. Y., Yuquan, Z., Yingwen, X., Xianhua, L., Wang, K. L., Wang, P. L., 1998, Diachronous uplift of the Tibet Plateau starting 40 Myr ago: Nature, v. 394, p. 769-773.

Chung, S. L., Liu, D., Ji, J., Chu, M. F., Lee, H. Y., Wen, D. J., Lo, C. H., Lee, T. Y., Qian, Q., and Zhang, Q., 2003, Adakites from continental collision zones: Melting of thickened lower crust beneath southern Tibet: Geology, v. 31, p. 1021-1024.

Copeland, P., Harrison, T. M., Yun, P., Kidd, W. S. F., Roden, M., and Zhang, Y., 1995, Thermal evolution of the Gangdese Batholith, southern Tibet; a history of episodic unroofing: Tectonics, v. 14, p. 223-236.

Coulon, C., Maluski, H., Bollinger, C., and Wang, S., 1986, Mesozoic and Cenozoic volcanic rocks from central and southern Tibet; ${ }^{39} \mathrm{Ar}^{40} \mathrm{Ar}$ dating, petrological characteristics and geodynamical significance: Earth and Planetary Science Letters, v. 79, p. 281-302.

DeCelles, P. G., Gehrels, G. E., Quade, J., Ojha, T. P., Kapp, P. A., and Upreti, B. N., 1998, Neogene foreland basin deposits, erosional unroofing, and the kinematic history of the Himalayan fold-thrust belt, western Nepal: Geological Society of America Bulletin, v. 110, p. 2-21.

DeCelles, P. G., Gehrels, G. E., Quade, J., LaReau, B., and Spurlin, M., 2000, Tectonic implications of U-Pb zircon ages of the Himalayan orogenic belt in Nepal: Science, v. 288, p. 497-499.

Debon, F., Zimmerman, J., Liu, G. H., Jin, C. W., and Xu, R. H., 1985, Time relationship between magmatism, tectonics and metamorphism in southern Tibet: new K-Ar data: Geology Rundsch, v. 74, p. 229-236. 
Debon, F., Le Fort, P., Sheppard, S. M. F., and Sonet, J., 1986, The four plutonic belts of the TranshimalayaHimalaya; a chemical, mineralogical, isotopic, and chronological synthesis along a Tibet-Nepal section: Journal of Petrology, v. 27, p. 219-250.

Dewey, J. F., Shackleton, R. M., Chengfa, C., and Yiyin, S., 1988, The tectonic evolution of the Tibetan Plateau: Philosophical Transactions of the Royal Society of London, Series A: Mathematical and Physical Sciences, v. 327, p. 379-413.

Ding, L., Zhong, D., Yin, A., Kapp, P., and Harrison, T. M., 2001, Cenozoic structural and metamorphic evolution of the eastern Himalayan syntaxis (Namche Barwa): Earth and Planetary Science Letters, v. 192 , p. $423-438$.

Ding, L., Kapp, P., Zhong, D., and Deng, W., 2003, Cenozoic Volcanism in Tibet: Evidence for a Transition from Oceanic to Continental Subduction: Journal of Petrology, v. 44, p. 1833-1865.

Edwards, M. A., and Harrison, T. M., 1997, When did the roof collapse? Late Miocene north-south extension in the high Himalaya revealed by Th-Pb monazite dating of the Khula Kangri Granite: Geology, v. 25, p. 543-546.

England, P. C., and Thompson, A. B., 1984, Pressure-temperature-time paths of regional metamorphism; II, Their inference and interpretation using mineral assemblages in metamorphic rocks: Journal of Petrology, v. 25, p. 929-955.

Ferrara, G., Lombardo, B., and Tonarini, S., 1983, Rb/Sr geochronology of granites and gneisses from the Mount Everest region, Nepal Himalaya: Geologische Rundschau, v. 72, p. 119-136.

Fielding, E., 1996, Tibet uplift and erosion: Tectonophysics, v. 260, p. 55-84.

Gehrels, G. E., DeCelles, P. G., Martin, A., Ojha, T. P., and Pinhassi, G., 2003, Initiation of the Himalayan orogen as an early Paleozoic thin-skinned thrust belt: GSA Today, v. 13, p. 4-9.

Geng, Q., Zheng, L., Pan, G., Ou, C., Sun, Z., Dong, H., Wang, X., Liu, Y., and Li, S., 2002, Ophiolitic Melanges in the Yarlung-Tsangpo "Big Bend" Canyon, SE Tibet: EOS, Transactions of the American Geophysical Union, v. 83, p. T51B-1145.

Hallet, B., and Molnar, P., 2001, Distorted drainage basins as markers of crustal strain east of the Himalaya: Journal of Geophysical Research, v. 106, p. 13,697-13,709.

Harris, N. B. W., and Inger, S., 1992, Trace element modelling of pelite-derived granites: Contributions to Mineralogy and Petrology, v. 110, p. 46-56.

Harris, N. B. W., and Massey, J., 1994, Decompression and anatexis of Himalayan metapelites: Tectonics, v. 13 , p. 1537-1546.

Harris, N. B. W., Inger, S., and Massey, J., 1993, The role of fluids in the formation of High Himalayan leucogranites, in Treloar, P. J., and Searle, M. P., Himalayan tectonics: Geological Society Special Publications, v. 74, p. 391-400.

Harrison, T. M., Copeland, P., Kidd, W. S. F., and Yin, A., 1992, Raising Tibet: Science, v. 255, p. 1663-1670.

Harrison, T. M., Ryerson, F. J., Le Fort, P., Yin, A., Lovera, O. M., and Catlos, E. J., 1997a, A Late Miocene-Pliocene origin for the Central Himalayan inverted metamorphism: Earth and Planetary Science Letters, v. 146, p. E1-E7.

Harrison, T. M., Lovera, O. M., and Grove, M., 1997b, New insights into the origin of two contrasting Himalayan granite belts: Geology, v. 25, p. 899-902.

Harrison, T. M., Grove, M., Lovera, O. M., and Catlos, E. J., 1998, A model for the origin of Himalayan anatexis and inverted metamorphism: Journal of Geophysical Research, v. 103, p. 27,017-27,032.

Harrison, T. M., Yin, A., Grove, M., Lovera, O. M., Ryerson, F. J., and Xinhua, Z., 2000, The Zedong Window; a record of superposed Tertiary convergence in southeastern Tibet: Journal of Geophysical Research, v. 105 , p. 19,211-19,230.

Hodges, K. V., 2000, Tectonics of the Himalaya and southern Tibet from two perspectives: GSA Bulletin, v. 112, p. 324-350.

Hodges, K. V., Parrish, R. R., Housh, T. B., Lux, D. R., Burchfiel, B. C., Royden, L. H., and Chen, Z., 1992, Simultaneous Miocene extension and shortening in the Himalayan Orogen: Science, v. 258, p. 1466 1470 .

Hodges, K. V., Parrish, R. R., and Searle, M. P., 1996, Tectonic evolution of the central Annapurna Range, Nepalese Himalayas: Tectonics, v. 15, p. 1264-1291.

Kapp, P., Murphy, M. A., Yin, A., Harrison, T. M., Ding, L., and Guo, J., 2003a, Mesozoic and Cenozoic tectonic evolution of the Shiquanhe area of western Tibet: Tectonics, v. 22, no. 4, 1029, doi:10.1029/ 2001 TC001332.

Kapp, P., Yin, A., Manning, C. E., Harrison, T. M., Taylor, M. H., and Ding, L., 2003b, Tectonic evolution of the early Mesozoic blueschist-bearing Qiangtang metamorphic belt, central Tibet: Tectonics, v. 22, no. 4, 1043, doi:10.1029/2002TC001383.

Kohn, M. J., and Parkinson, C. D., 2002, Petrologic case for Eocene slab breakoff during the Indo-Asian collision: Geology, v. 30, p. 591-594

Koons, P. O., Craw, D., Cox, S. C., Upton, P., Templeton, A. S., and Chamberlain, C. P., 1998, Fluid flow during active oblique convergence; a Southern Alps model from mechanical and geochemical observations: Geology, v. 26, p. 159-162.

Koons, P. O., Zeitler, P. K., Chamberlain, C. P., Craw, D., and Meltzer, A. S., 2002, Mechanical links between erosion and metamorphism in Nanga Parbat, Pakistan Himalaya: American Journal of Science, v. 302 , p. 749-773.

Kosarev, G., Kind, R., Sobolev, S. V., Yuan, X., Hanka, W., and Oreshin, S., 1999, Seismic evidence for a detached Indian lithospheric mantle beneath Tibet: Science, v. 283, p. 1306-1309.

Lee, H. Y., Chung, S. L., Wang, J. R., Wen, D. J., Lo, C. H., Yang, T. F., Zhang, Y., Xie, Y., Lee, T. Y., Wu, G., and Ji, J., 2003, Miocene Jiali faulting and its implications for Tibetan tectonic evolution: Earth and Planetary Science Letters, v. 205, p. 185-194. 
Le Fort, P., 1975, Himalaya: the collided range. Present knowledge of the continental arc: American Journal of Science, v. 275, p. 1-44.

_ 1981, Manaslu leucogranite: A collision signature of the Himalaya, a model for its genesis and emplacement: Journal of Geophysical Research, v. 86, p. 10545-10568.

Le Fort, P., Debon, F., and Sunet, J., 1980, The "Lesser Himalayan" cordierite granite belt, typology and age of the pluton of Manserah (Pakistan), in Tahirkheli, R. A. K., Jan, M. Q., and Majid, M., editors, Proceedings of the International Committee on Geodynamics Group 6 meeting: Geological Bulletin, University of Peshawar special issue, v. 13, p. 51-61.

Le Fort, P., Debon, F., Pecher, A., Sonet, J., and Vidal, P., 1986, The 500 Ma magmatic event in Alpine southern Asia, a thermal episode at Gondwana Scale: Sciences de la Terre, Mémories, v. 47, p. 191-209.

Le Fort, P., Cuney, M., Deniel, C., France-Lanord, C., Sheppard, S. M. F., Upretti, B. N., and Vidal, P., 1987, Crustal generation of the Himalayan leucogranites: Tectonophysics, v. 134, p. 39-57.

Leloup, P. H., and Kienast, J. R., 1993, High-temperature metamorphism in a major strike-slip shear zone; the Ailao Shan-Red River, People's Republic of China: Earth and Planetary Science Letters, v. 118, p. 213-234.

Leloup, P. H., Harrison, T. M., Ryerson, F. J., Wenji, Chen, Qi, Li, Tapponnier, P., and Lacassin, R., 1993, Structural, petrological and thermal evolution of a Tertiary ductile strike-slip shear zone, Diancang Shan, Yunnan: Journal of Geophysical Research, v. 98, p. 6715-6743.

Leloup, P. H., Lacassin, R., Tapponnier, P., Schaerer, U., Z. Dalai, L. Xiaohan, Zhang, L., J. Shaocheng, and Trinh, P. T., 1995, The Ailao Shan-Red River shear zone (Yunnan, China), Tertiary transform boundary of Indochina: Tectonophysics, v. 251, p. 3-84.

Leloup, P. H., Ricard, Y., Battaglia, J., and Lacassin, R., 1999, Shear heating in continental strike-slip shear zones; model and field examples: Geophysical Journal International, v. 136, p. 19-40.

Liu, Y., and Zhong, D., 1997, Petrology of high-pressure granulites from the eastern Himalayan syntaxis: Journal of Metamorphic Geology, v. 15, p. 451-466.

Ludwig, K. R., 2001, User's Manual for Isoplot/Ex, Version 2.49, A Geochronological Toolkit for Microsoft Excel: Berkeley Geochronology Center Special Publication No. 1a, 55 p.

Maheo, G., Guillot, S., Blichert-Toft, J., Rolland, Y., and Pecher, A., 2002, A slab breakoff model for the Neogene thermal evolution of South Karakorum and South Tibet: Earth and Planetary Science Letters, v. 195 , p. $45-58$.

Maluski, H., Matte, P., and Brunel, M., 1988, Argon 39-Argon 40 dating of metamorphic and plutonic events in the North and High Himalaya belts (southern Tibet-China): Tectonics, v. 7, p. 299-326.

Meyer, B., Tapponnier, T., Bourjot, L., Metivier, F., Gaudemer, Y., Peltzer, G., Shunmin, G., and Zhitai, C., 1998, Crustal thickening in Gansu-Qinghai, lithospheric mantle subduction, and oblique, strike-slip controlled growth of the Tibet Plateau: Geophysical Journal International, v. 135, p. 1-47.

Miller, C., Schuster, R., Kloetzli, U. S., and Frank, W., 1999, Purtscheller, F., Post-collisional potassic and ultrapotassic magmatism in SW Tibet; geochemical and Sr-Nd-Pb-O isotopic constraints for mantle source characteristics and petrogenesis: Journal of Petrology, v. 40, p. 1399-1424.

Miller, C., Thoni, M., Frank, W., Grazemann, B., Kloetzli, U. S., Guntli, P., and Dragnitis, E., 2001, The early Paleozoic magmatic event in the northwest Himalaya, India: source, tectonic setting and age of emplacement: Geological Magazine, v. 138, p. 237-251.

Molnar, P., England, P., and Martinod, J., 1993, Mantle dynamics, the uplift of the Tibetan plateau, and the Indian monsoon: Reviews of Geophysics, v. 31, p. 357-296.

Murphy, M. A., and Harrison, T. M., 1999, Relationship between leucogranites and the Qomolangma detachment in the Rongbuk Valley, south Tibet: Geology, v. 27, p. 831-834.

Murphy, M. A., and Yin, A., 2003, Structural evolution and sequence of thrusting in the Tethyan fold-thrust belt and Indus-Yalu suture zone, southwest Tibet: Geological Society of America Bulletin, v. 115, p. 21-34.

Murphy, M. A., Yin, A., Harrison, T. M., Dürr, S. B., Chen, Z., Ryerson, F. J., Kidd, W. S. F., Wang, X., and Zhou, X., 1997, Did the Indo-Asian collision alone create the Tibetan plateau?: Geology, v. 25, p. 719-722.

Nash, W. P., and Crecraft, H. R., 1985, Partition coefficients for trace elements in silicic magmas: Geochimica et Cosmochimica Acta, v. 49, p. 2309-2322.

Pearce, J. A., 1996, A user's guide to basalt discrimination diagrams, in Wyman, D. A., editors, Trace Element Geochemistry of Volcanic Rocks: Applications for Massive Sulphide Exploration: Geological Association of Canada, Short Course Notes v. 12, p. 79-113.

Pearce, J. A., Harris, N., and Tindle, A., 1984, Trace element discrimination diagrams for the tectonic interpretation of granitic rocks: Journal of Petrology, v. 25, p. 956-983.

Quidelleur, X., Grove, M., Lovera, O. M., Harrison, T. M., Yin, A., and Ryerson, F. J., 1997, Thermal evolution and slip history of the Renbu Zedong Thrust, southeastern Tibet: Journal of Geophysical Research, v. 102, p. 2659-2679.

Ratschbacher, L., Frisch, W., Liu, G., and Chen, C. C., 1994, Distributed deformation in southern and western Tibet during and after the India-Asia collision: Journal of Geophysical Research, v. 99 p. $19,917-19,945$.

Scaillet, B., Pecher, A., Rochette, P., and Champenois, M., 1995, The Gangotri granite (Garhwal Himalaya): laccolith emplacement in an extending collisional belt: Journal of Geophysical Research, v. 100, p. 585-607.

Schärer, U., Xu, R. H., and Allegre, C. J., 1984, U-Pb geochronology of Gangdese (Transhimalaya) plutonism in the Lhasa-Xigaze region, Tibet: Earth and Planetary Science Letters, v. 69, p. 311-320.

Schärer, U., Tapponnier, P., Lacassin, R., Leloup, P. H., Zhong Dalai, and Ji, S., 1990, Intraplate tectonics in Asia: A precise age for large-scale Miocene movement along the Ailao Shan - Red River shear zone, China: Earth and Planetary Science Letters, v. 97, p. 65-77. 
Schärer, U., Zhang L.S., and Tapponnier, P., 1994, Duration of strike-slip movements in large shear zones: The Red River belt, China: Earth and Planetary Science Letters, v. 126, p. 379-397.

Stacey, J. S., and Kramers, J. D., 1975, Approximation of terrestrial lead isotopic evolution by a two-stage model: Earth and Planetary Science Letters, v. 26, p. 207-221.

Tilmann, F., Ni, J., Hearn, T., Ma, Y. S., Rapine, R., Kind, R., Mechie, J., Saul, J., Haines, S., Klemperer, S., Brown, L., Pananont, P., Ross, A., Nelson, K. D., Guo, J., and Zhao, W., 2003, Seismic imaging of the downwelling Indian lithosphere beneath central Tibet: Science, v. 300, p. 1424-1427.

Trivedi, J. R., Gopalan, K., and Valdiya, K. S., 1984, Rb-Sr ages of granitic rocks within the Lesser Himalayan nappes, Kumaun, India: Journal of the Geological Society of India, v. 25, p. 641-654

Turner, S., Arnaud, N., Liu, J., Rogers, N., Hawkesworth, C., Harris, N., Kelley, S., van Calsteren, P., and Deng, W., 1996, Postcollision, shoshonitic volcanism on the Tibetan Plateau: Implications for convective thinning of the lithosphere and the source of ocean island basalts: Journal of Petrology, v. 37, p. 45-71.

Wang, E., and Burchfiel, B. C., 1997, Interpretation of Cenozoic tectonics in the right-lateral accommodation zone between the Ailao Shan shear zone and the eastern Himalayan syntaxis: International Geology Review, v. 39, p. 191-219.

Wang, J., Yin, A., Harrison, T. M., Grove, M., Yuquan, Z., and Guanghong, X., 2001, A tectonic model for Cenozoic igneous activities in the eastern Indo-Asian collision zone: Earth and Planetary Science Letters, v. 188, p. 123-133.

Whittington, A. G., and Treloar, P. J., 2002, Crustal anatexis and its relation to the exhumation of collisional orogenic belts, with particular reference to the Himalaya: Mineralogical Magazine, v. 66, p. 53-91.

Whittington, A. G., Harris, N. B. W., and Butler, R. W. H., 1999, Contrasting anatectic styles at Nanga Parbat, northern Pakistan, in Macfarlane, A., Sorkhabi, R. B., and Quade, J., editors, Himalaya and Tibet; mountain roots to mountain tops: Boulder, Colorado, Geological Society of America Special Paper, v. 328, p. $129-144$

Williams, H., Turner, S., Kelley, S., and Harris, N., 2001, Age and composition of dikes in southern Tibet: New constraints on the timing of east-west extension and its relationship to postcollisional magmatism: Geology, v. 29, p. 339-342.

Williams, I. S., 1998, U-Th-Pb Geochronology by Ion Microprobe, in McKibben, M. A., Shanks III, W. C., and Ridley, W. I., editors, Applications of Microanalytical Techniques to Understanding Mineralizing Processes: Society of Economic Geologists, review v. 7, p. 1-35.

Winslow, D. M., Chamberlain, C. P., and Zeitler, P. K., 1995, Metamorphism and melting of the lithosphere due to rapid denudation, Nanga Parbat Massif, Himalaya: Journal of Geology, v. 103, p. 395-409.

Yin, A., 2000, Mode of Cenozoic east-west extension in Tibet suggesting a common origin of rifts in Asia during the Indo-Asian collision: Journal of Geophysical Research, B, Solid Earth and Planets, v. 105, p. 21,745-21,759.

Yin, A., and Harrison, T. M., 2000, Geologic evolution of the Himalayan-Tibetan orogen: Annual Review of Earth and Planetary Sciences, v. 28, p. 211-280.

Yin, A., Harrison, T. M., Ryerson, F. J., Chen, W., Kidd, W. S. F., and Copeland, P., 1994, Tertiary structural evolution of the Gangdese thrust system, southwestern Tibet: Journal of Geophysical Research, v. 99 p. 18,175-18,201.

Yin, A., Harrison, T. M., Murphy, M. A., Grove, M., Nie, S., Ryerson, F. J., Feng, W. X., and Le, C. Z., 1999 Tertiary deformation history of southeastern and southwestern Tibet during the Indo-Asian collision: Geological Society of America Bulletin, v. 111, p. 1644-1664.

Zeitler, P. K., and Chamberlain, C. P., 1991, Petrogenetic and tectonic significance of young leucogranites from the NW Himalaya, Pakistan: Tectonics, v. 10, p. 729-741.

Zeitler, P. K., Chamberlain, C. P., and Smith, H., 1993, Synchronous anatexis, metamorphism, and rapid denudation at Nanga Parbat, Pakistan Himalaya: Geology, v. 21, p. 347-350.

Zeitler, P. K., Meltzer, A. S., Koons, P. O., Craw, D., Hallet, B., Chamberlain, C. P., Kidd, W. S. F., Park, S. K. Seeber, L., Bishop, M., and Shroder, J., 2001a, Erosion, Himalayan geodynamics, and the geomorphology of metamorphism: GSA Today, 11, p. 4-8.

Zeitler, P. K., Koons, P. O., Bishop, M. P., Chamberlain, C. P., Craw, D., Edwards, M. A., Hamidullah, S., Jan, M. Q., Khan, M., Khattak, M., Kidd, W. S. F., Mackie, R. L., Meltzer, A. S., Park, S. K., Pecher, A., Poage, M. A., Sarker, G., Schneider, D. A., Seeber, L., and Shroder, J. F., 2001b, Crustal reworking at Nanga Parbat, Pakistan; metamorphic consequences of thermal-mechanical coupling facilitated by erosion: Tectonics, v. 20, p. 712-728.

Zhang, L. S., and Schärer, U., 1999, Age and origin of magmatism along the Cenozoic Red River shear belt, China: Contributions to Mineralogy and Petrology, v. 134, p. 67-85.

Zhang, Z. G., Liu, Y. H., Qnag, H. X., and Xu, B. C., 1992, Geology of the Namche Barwa Region: Beijing, Chinese Science Press, 185 p. 